DOI: https://doi.org/10.47405/mjssh.v6i2.683

\begin{tabular}{|c|c|}
\hline$x=$ & Malaysian Journal of Social Sciences and Humanities (MJSSH) \\
\hline Malaysian Journal of & Volume 6, Issue 2, February 2021 \\
\hline (MJ-ssH) & e-ISSN : 2504-8562 \\
\hline & $\begin{array}{l}\text { Journal home page: } \\
\text { www.msocialsciences.com }\end{array}$ \\
\hline
\end{tabular}

\title{
Konsep Kendiri dan Gaya Pembelajaran terhadap Motivasi Akademik dalam kalangan Mahasiswa
}

\author{
Farah Wazera Mohamed Jaafer Sadiq ${ }^{1}$, Mohammad Mujaheed Hassan ${ }^{1}$ \\ ${ }^{1}$ Jabatan Sains Kemasyarakatan dan Pembangunan, Fakulti Ekologi Manusia, Universiti Putra Malaysia (UPM) \\ Correspondence: Mohammad Mujaheed Hassan (mujaheed@upm.edu.my)
}

\begin{abstract}
Abstrak
Kepercayaan terhadap diri sendiri adalah sangat penting untuk memastikan individu sentiasa berfikiran positif dan terus semangat dalam menjalani kehidupan seharian sebagai seorang pelajar. Gaya pembelajaran yang betul juga adalah penting untuk pastikan seseorang itu terus cemerlang dan yakin dalam urusan akademik. Statistik dunia menunjukkan bahawa seramai $11.5 \%$ pelajar Korea Selatan bunuh diri akibat tertekan dengan ujian sekolah. Terdapat kes di Malaysia di mana pelajar cemerlang SPM bunuh diri akibat tidak mempunyai keyakinan dalam pelajaran. Objektif kajian ini bertujuan untuk mengkaji tahap, perhubungan dan perbezaan antara konsep kendiri, gaya pembelajaran dengan motivasi akademik. Kajian ini dilakukan di Universiti Putra Malaysia dalam kalangan mahasi swa tahun pertama sesi 2019/2020. Seramai 251 responden libatkan diri dalam kajian ini. Kajian ini adalah berbentuk kuantitatif dan responden dipilih melalui persampelan bertujuan mudah. Seterusnya, melalui persampelan rawak berstrata, 234 mahasiswa perempuan dan 117 mahasiswa lelaki telah dibahagikan. Instrumen kajian menggunakan borang soal selidik yang terdiri dari empat bahagian iaitu Bahagian A (latar belakang responden), Bahagian B (konsep kendiri), Bahagian C (gaya pembelajaran) dan Bahagian D (motivasi akademik). Hasil kajian dianalisis menggunakan analisis deskriptif, korelasi pearson dan ujian-T. Hasil kajian menunjukkan bahawa mahasiswa tahun pertama di Universiti Putra Malaysia memiliki tahap konsep kendiri, motivasi akademik intrinsik dan motivasi akademik ekstrinsik yang tinggi. Responden juga didapati lebih cenderung dengan gaya pembelajaran visual dan kinestetik berbanding gaya pembelajaran auditori. Bagi perkaitan antara konsep kendiri dan motivasi akademik, didapati terdapat perhubungan yang positif di mana dilihat konsep kendiri mempengaruhi motivasi akademik. Dapatan kajian juga menunjukkan bahawa gaya pembelajaran visual dan kinestetik mempengaruhi motivasi akademik responden. Hasil kajian mendapati bahawa terdapat perbezaan yang signifikan antara konsep kendiri, gaya pembelajaran visual dan motivasi akademik dengan jantina. Berdasarkan skor min dapat dilihat perempuan mendapat skor min yang lebih tinggi berbanding lelaki. Secara keseluruhan, kajian ini telah berjaya mencapai objektif yang telah dinyatakan. Ibu bapa, guru dan pelajar itu sendiri haruslah memainkan peranan yang penting untuk memastikan motivasi akademik sentiasa berada di tahap yang tinggi.
\end{abstract}

Kata kunci: konsep kendiri, gaya pembelajaran, motivasi akademik

\section{Self-Concept and Learning Style towards Academic Motivation among University Students}

Abstract 
Belief in oneself is very important to ensure that individuals always think positive and keep the spirit in their daily life as a student. Correct learning style is also important to make sure that the person continues to be excellent and confident in academic affairs. World statistics show that as many $11.5 \%$ of South Korea students committed suicide due to stress with school exams. There are cases, in which excellent SPM students commit suicide due to lack confidence in her studies. The objective of this study was to investigate the level, relationship and differences between self-concept, learning style and academic motivation. This study was conducted at Universiti Putra Malaysia among first-year students session 2019/2020. A total of 251 respondents involved in this study. This study is a quantitative and respondents were selected through purposive convenient sampling. Next, by using stratified random sampling, 234 female students and 117 male students were divided. The instrument uses questionnaire consisting of four parts, namely Part A (demographic background), Part B (self-concept), Part C (learning styles) and Part D (academic motivation). The results were analyzed using descriptive analysis, Pearson correlation and T-Test. The results showed that first-year students at the Universiti Putra Malaysia has a high level of self-concept, intrinsic academic motivation and extrinsic academic motivation. Respondents more dominant with visual and kinesthetic learning styles than auditory learning style. As for the relationship between self-concept and academic motivation, there was a positive relationship which sees academic self-concept affects academic motivation. The findings also showed that visual and kinesthetic learning styles affect the motivation of academic respondents. The results showed that there were significant differences between self-concept, visual learning style and academic motivation among gender. Based on the score mean, female has a higher score mean than male. Overall, this study was able to achieve the objectives that have been stated. Parents, teachers and students themselves must play an important role in ensuring academic motivation has always been at a high level.

Keywords: self-concept, learning styles, academic motivation

\section{Pengenalan}

Setiap manusia di muka bumi tidak pernah berhenti untuk belajar dalam kehidupan. Bermula dari sistem pendidikan, misalnya apabila harus menghadiri kursus, juga di tempat kerja dan dalam proses menjalani kehidupan seharian, pelbagai perkara yang baru akan kita pelajari. Dalam dunia yang moden dan serba canggih ini, seseorang itu haruslah menyesuaikan diri dengan masa dan dapat memulakan tugas. Jelas terbukti, adalah sangat penting untuk belajar dan tahu gaya pembelajaran yang betul kerana gaya pembelajaran merupakan kunci kepada pengetahuan dan kejayaan seseorang.

Gaya pembelajaran adalah cara yang konsisten untuk bertindak dan menggunakan rangsangan dalam konteks pembelajaran. Dengan kata lain, gaya pembelajaran bukan menekankan apa yang dipelajari tetapi bagaimana seseorang itu memilih cara untuk belajar. Pembelajaran juga adalah usaha dalam menguasai dan memahami konsep dan dapat mengaplikasikan dalam kehidupan. Penyesuaian diri antara gaya pembelajaran dengan aktiviti adalah amat penting bagi mengelakkan wujudnya perasaan tidak berminat untuk belajar akibat kebosanan dalam belajar.

Setiap individu mempunyai gambaran atau persepsi tentang diri sendiri. Persepsi inilah yang disebut sebagai konsep kendiri. Sebagai contoh gambaran tentang rupa paras, fizikal, kebolehan, kelemahan, kesihatan dan tingkah laku seseorang itu disebut sebagai konsep kendiri. Konsep kendiri boleh didefinisikan sebagai persepsi individu tentang dirinya, penilaian individu tentang persepsi orang lain terhadapnya dan penilaian orang lain akan diri individu. Konsep kendiri dan motivasi akademik adalah kepercayaan tentang diri sendiri yang berkait rapat dengan keupayaan akademik, tugas dan aktiviti.

Konsep kendiri juga boleh dianalogikan sebagai satu sistem, operasi yang menjalankan komputer mental di mana dapat mempengaruhi kemampuan berfikir dan sebenarnya mempengaruhi sebanyak 88\% dalam tahap kesedaran seseorang. Konsep kendiri boleh dibahagikan kepada dua iaitu yang positif dan negatif. Konsep kendiri negatif sentiasa merasakan diri mereka lemah, tidak dapat membuat apa-apa, kurang kompeten dan kehilangan daya tarikan dalam hidup. Manakala, individu 
dengan konsep kendiri yang positif sebenarnya lebih menghargai diri mereka dan sentiasa beranggapan positif.

Pelajar yang sentiasa bermotivasi dalam pelajaran akan sentiasa kekal fokus di dalam kelas dan mereka akan sedia bersemangat untuk belajar sesuatu yang baru. Pelajar yang tidak bermotivasi akan sentiasa tidak berminat untuk belajar apa yang diajar oleh guru tetapi akan memaksa diri untuk mempelajarinya. Hal ini secara tidak langsung dapat menimbulkan rasa benci terhadap pelajaran bahkan untuk masa akan datang pelajar tidak akan lagi mempunyai keinginan untuk mempelajarinya. Apabila kehilangan rasa minat dalam belajar, maka boleh menyebabkan pelajar bertindak untuk ponteng sekolah kerana merasakan sia-sia sahaja apa yang akan dipelajarinya.

Usaha kerajaan dalam melaksanakan dasar pendidikan kebangsaan adalah satu inisiatif yang penting untuk menimbulkan kesedaran tentang betapa pentingnya untuk memiliki satu sistem pendidikan kebangsaan yang efektif. Pelbagai strategi telah dilaksanakan untuk mencapai matlamat dasar pendidikan, iaitu dengan mewujudkan sistem peperiksaan yang sama bagi semua. Dengan begini pelajar akan merasakan pembelajaran ini adalah adil kerana soalan-soalan yang akan ditanyakan adalah pada tahap yang sama. Seterusnya adalah mempertingkatkan pendidikan kerohanian, moral dan disiplin.

Selain itu, kerajaan juga mempelbagaikan dan memperbanyakkan kemudahan pendidikan di peringkat universiti. Hal ini akan memudahkan para pelajar untuk mendapatkan bahan rujukan atau untuk menambah pengetahuan. Dengan adanya pelbagai kemudahan, motivasi pelajar untuk belajar akan sentiasa di tahap yang tinggi kerana merasakan belajar itu adalah sesuatu yang mudah. Usaha lain adalah dengan menggalakkan aktiviti ko-kurikulum. Aktiviti ini dapat memupuk disiplin dan semangat berpasukan. Pelajar juga akan berasa yakin dengan diri sendiri dan sentiasa rasa bertenaga.

Dalam usaha meningkatkan kesedaran tentang pentingnya belajar, akademi "ZAGAZIG PANELIST" telah mengadakan kempen "JOM PAKAT STUDY!!". Objektif kempen ini adalah pelajar haruslah belajar dua jam setiap hari. Kedua, sentiasa bersedia untuk hadapi peperiksaan. Ketiga adalah mewujudkan semangat dan suasana ketika berada di rumah. Menurut mereka, seseorang itu haruslah melakukan sesuatu yang tidak mudah dan selesa untuk dilakukan. Keyakinan dan pengorbanan amatlah penting untuk berjaya. Keinginan untuk terus belajar dalam menemukan idea baru serta ilmu untuk selesaikan sesuatu masalah akan sentiasa membantu seseorang untuk sentiasa membantu minda agar kekal aktif.

Seseorang yang mempercayai dirinya sendiri akan mengelakkan diri dari ragu-ragu dan yakin terhadap apa yang dilakukan. Dalam menambah kepercayaan dan pemahaman terhadap diri, pendidikan adalah sangat penting dalam dunia yang sangat kompetitif dan penuh cabaran. Belajar merupakan perkara yang sangat penting untuk bantu kita membangun secara mental. Setiap orang haruslah berusaha untuk memastikan diri ini sentiasa positif dan bermotivasi selalu. Oleh itu, kajian ini akan dilakukan untuk melihat bagaimana konsep kendiri dan gaya pembelajaran berhubung kait.

\section{Penyataan Masalah}

Menurut laporan Organisasi Kesihatan Dunia (WHO) 2017, dianggarkan kadar pembunuhan diri di Korsel mencapai 14.8 per 100 ribu penduduk pada tahun 2000, 34.1 per 100 ribu pada tahun 2010, dan 28.3 per 100 ribu pada tahun 2015. Sebanyak 139 siswa di Korea Selatan membunuh diri sepanjang tahun 2012 lalu. 40\% bunuh diri kerana menghadapi masalah yang berkaitan dengan keluarga, 16\% kerana depresi, dan $11.5 \%$ adalah kerana tekanan akibat ujian sekolah. Daripada 139 siswa, 88 siswa yang bunuh diri berasal dari sekolah menengah atas, 48 dari sekolah menengah pertama dan tiga dari sekolah dasar.

Terdahulu menurut Kajian Kesihatan Mobiliti Kebangsaan (NHMS) 2017, sebuah kajian dibuat ke atas 30,496 sampel yang terdiri pelajar sekolah menengah berumur 13 hingga 17 tahun di 212 sekolah seluruh Malaysia. Didapati 11.2 peratus remaja dalam kelompok itu mempunyai idea untuk 
membunuh diri, sembilan peratus merancang untuk bunuh diri dan 10.1 peratus melakukan cubaan untuk bunuh diri. Menurut menteri pendidikan, 1.4\% iaitu bersamaan 67,053 pelajar mencatat rekod tertinggi ponteng sekolah pada tahun 2017.

Pada tahun 2017, 'Hasil Tinjauan Kesihatan Remaja Kebangsaan 2017' mendapati bahawa peratusan pelajar sekolah menengah di Pulau Pinang yang melakukan percubaan membunuh diri ialah sebanyak $6 \%$. Hasil didapati sebanyak $18.5 \%$ pelajar sekolah menengah di negeri pulau pinang mengalami kemurungan dan $9.5 \%$ pernah merancang untuk membunuh diri. Perhatian khusus haruslah diberikan kerana pelajar yang terlibat perlukan sokongan dari masyarakat sekeliling. Ibu bapa haruslah bertindak dengan segera jika mendapati anak mereka mempunyai tanda-tanda kemurungan.

Sebuah kes yang terjadi di mana seorang pelajar sekolah asrama di Sikar, Jaipur bernama Kumawat, 17 tahun telah membunuh diri dengan melompat dari tingkat enam bangunan di Sikar pada hari Isnin, 12 Mac 2019 akibat tekanan peperiksaan. Mangsa merupakan pelajar sekolah menengah yang mengikuti aliran sains matematik. 10 minit sebelum peperiksaan tamat, mangsa sedar helaian terakhir kertas itu melekat dan menyedari masih belum menjawab lima soalan. Mangsa terus berasa gelisah dan memaklumkan hal berkenaan kepada guru yang menjaga dewan peperiksaan.

Guru berkenaan memberi masa tambahan lima minit kepada mangsa namun masih tidak dapat menghabiskannya kerana terlampau gelisah dan takut. Kawan-kawannya cuba memberi motivasi kepadanya tetapi usaha itu sia-sia. Sejurus keluar dari dewan peperiksaan, mangsa telah terjun bangunan. Orang ramai terkejut melihat mayat mangsa yang berlumuran darah terbaring di jalan raya. Siasatan mendapati mangsa adalah seorang pelajar yang bijak kerana memperoleh $87 \%$ dalam peperiksaan sebeum ini (Correspondent, 2019).

Menurut berita Astro Awani (2018) terdapat satu lagi kes dimana pelajar perempuan gantung diri di kipas. Mangsa berasal dari New Delhi dan berumur 15 tahun .Mangsa telah diganggu secara seksual sehingga mengakibatkan kemurungan. Mangsa yang terlampau kecewa dan tertekan meluahkan rasanya di kertas yang berbunyi "Saya gagal.. Saya bodoh.. Saya benci diri saya..". Menurut ibu bapa mangsa, mangsa pernah disentuh dengan cara tak sepatutnya oleh dua orang guru di sekolahnya. Mangsa sangat takut kerana gurunya akan sentiasa sengaja menggagalkannya dalam peperiksaan.

Kes ketiga dimana seorang pelajar lelaki tikam diri kerana tekanan akibat pelajaran. Mangsa merupakan seorang pelajar di kolej swasta yang sepatutnya telah tamat pengajian tetapi disebabkan gagal beberapa subjek, mangsa perlu menduduki peperiksaan ulangan hanya lagi dua hari. Beberapa hari sebelum kejadian, mangsa pernah meluahkan rasa tertekannya dalam pelajaran kepada kakaknya. Akibat tidak dapat mengawal diri pelajar kolej swasta tersebut telah menikam dirinya di perut awal pagi di sebuah rumah di I-Mas Village, Kota Samarahan ("Pelajar tikam diri dipercayai stres akibat pelajaran", 2018).

Kes keempat berlaku pada tahun 2018 di mana seorang pelajar 10A SPM terjun bangunan. Seorang pelajar cemerlang SPM wanita maut selepas terjun dari tingkat 14, pangsapuri di seremban kerana mengalami kemurungan yang melampau. Mangsa pada awalnya telah menyambung pelajaran di IPTA di Kedah namun dikatakan mengalami kemurungan dan dia dipindahkan di institusi yang lain di Seremban. Ibu bapanya juga telah memasang aplikasi GPS pada telefon bimbit anak perempuan kerana risau dengan keadaannya dan untuk sentiasa mengesan lokasi anak mereka.

Setelah beberapa ketika tidak dapat mengesan anak mereka, ibu bapa mangsa mendapat panggilan yang menyatakan mangsa terjun bangunan. Turut dijumpai nota bersamanya yang berbunyi, "Jika anda menemui saya dalam keadaan masih hidup, tolong suruh doktor jangan selamatkan saya.".Mangsa meluahkan perasaan dirinya yang sangat tertekan kerana tidak dapat fokus pelajaran dengan baik (Razak, 2018). Pelajar yang rasa tertekan seharusnya cuba mendapatkan nasihat yang lebih pakar. Satu kajian tentang "Sikap dan motivasi pelajar terhadap pembelajaran Bahasa Melayu" telah dilakukan dan kajian itu adalah tentang sikap pelajar dalam pembelajaran dan sampai tahap manakah motivasi pelajar dalam pelajaran tersebut. Hasil yang dibincangkan adalah, jika ingin memotivasikan pelajar, pelajar haruslah menguasai pelajaran tersebut. Selain itu, kata-kata yang 
positif juga haruslah sentiasa diberikan oleh guru. Hasil kajian juga menunjukkan bahawa masyarakat sekeliling memainkan peranan penting dalam meningkatkan motivasi pelajar (Nasir \& Hamzah, 2013).

Berdasarkan kajian lepas yang telah dijalankan oleh pengkaji tentang bagaimana motivasi, gaya pembelajaran dan pencapaian akademik adalah saling berhubung kait. Terdapat pelbagai gaya pembelajaran yang boleh diamalkan oleh pelajar mengikut kesesuaian masing-masing. Dengan menggunakan gaya pelajaran yang bersesuaian, ia dapat meningkatkan pencapaian para pelajar. Kajian ini dapat membantu guru mengenal pasti gaya pembelajaran jenis manakah yang bersesuaian dengan pelajar. Dengan ini, proses pengajaran dan pembelajaran juga dapat berjalan dengan baik (Aziz et al., 2006). Untuk mengupas lebih tentang motivasi, kajian yang akan dilakukan adalah tentang konsep kendiri dan gaya pembelajaran dan hubung kaitnya dengan motivasi akademik. Pemahaman diri adalah sangat penting untuk memastikan individu sentiasa berfikiran positif dan terus semangat dalam menjalani kehidupan harian. Gaya pembelajaran yang betul juga sangatlah penting untuk memastikan seseorang terus cemerlang dalam akademik.

\section{Objektif Kajian}

Secara amnya, kajian ini bertujuan untuk mengkaji konsep kendiri dan gaya pembelajaran dengan motivasi akademik dalam kalangan mahasiswa tahun pertama. Terdapat empat (4) objektif khusus dalam kajian ini iaitu:-

i. Untuk memerihalkan latar belakang responden yang terlibat dalam kajian ini.

ii. Untuk mengukur tahap konsep kendiri, gaya pembelajaran dan motivasi akademik dalam kalangan mahasiswa tahun pertama.

iii. Untuk mengkaji perhubungan antara konsep kendiri dan gaya pembelajaran dengan motivasi akademik dalam kalangan mahasiswa tahun pertama.

iv. Untuk mengkaji perbezaan konsep kendiri, gaya pembelajaran dan motivasi akademik dalam kalangan mahasiswa tahun pertama antara lelaki dan perempuan

\section{Kerangka Konseptual dan Operasional}

\section{Konsep Kendiri}

Konseptual: Penilaian seseorang ke atas dirinya sendiri atau bagaimana ia menganggap tentang dirinya sendiri sama ada secara positif atau negatif (Epstein, 1980).

Operasional: Konsep kendiri boleh diukur dari segi konsep kendiri akademik dan bukan akademik yang diadaptasi dari Marzuki Ngah (2002). Purata skor yang tinggi pada instrumen konsep kendiri akan menggambarkan tahap konsep kendiri yang tinggi bagi responden

\section{Gaya Pembelajaran}

Konseptual: Gaya pembelajaran adalah cara seseorang individu menumpukan perhatiannya untuk memahami dan mengingati sesuatu maklumat atau kemahiran baru (Dunn \& Dunn, 1978).

Operasional: Gaya pembelajaran di sekolah dikenalpasti melalui pemarkahan responden yang diadaptasi dari satu set soal selidik 'Learning Channel Preference' oleh O'Brien (1985). Ia adalah untuk mengenal pasti pemilihan tiga jenis gaya pembelajaran iaitu auditori, visual dan kinestetik.

\section{Motivasi Akademik}

Konseptual: Motivasi adalah keinginan yang keras atau semangat yang kuat pada diri seseorang yang mendorongnya untuk berusaha atau melakukan sesuatu dengan tujuan untuk mencapai kejayaan (Kamus Dewan, Edisi Ketiga, 2002). 
Operasional: Motivasi akademik dalam kalangan pelajar boleh diukur dengan motivasi intrinsik, motivasi ekstrinsik dan amotivasi yang diadaptasi dari skala akademik motivasi oleh Vallerand (1992). Motivasi intrinsik terbahagi kepada tiga iaitu to know, towards accomplishment, to experience stimulation. Manakala motivasi ekstrinsik juga terbahagi kepada tiga iaitu identified, introjeted dan external regulation

\section{Kerangka Konseptual}

Rajah 1: Kerangka konseptual kajian

Angkubah Antisiden

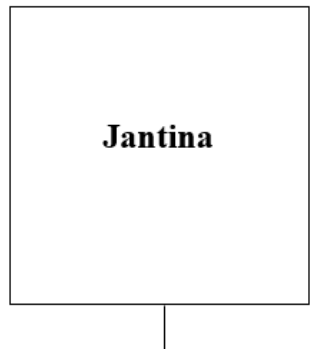

Angkubah Tidak Bersandar Angkubah Bersandar

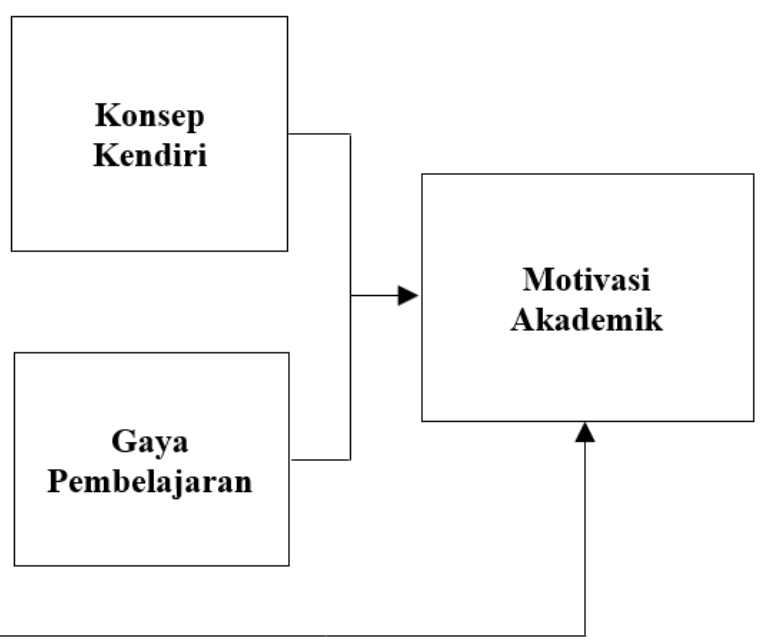

\section{Kajian Literatur}

\section{Pengertian Konsep Kendiri}

Definisi konsep diri menurut beberapa ahli berbeza namun memiliki penekanan yang sama terhadap cara pandang diri, iaitu: Konsep diri merupakan semua idea, pemikiran, kepercayaan dan pendirian yang diketahui individu tentang dirinya dan mempengaruhi individu dalam berhubung dengan orang lain (Stuart \& Sudeen, 1998). Konsep diri adalah perasaan, kepercayaan dan nilai yang diketahui individu tentang dirinya dan mempengaruhi individu dalam berhubungan dengan orang lain (Tarwoto \& Wartonah, 2003). Menurutnya juga, terdapat beberapa ciri konsep kendiri yang rendah iaitu mengelakkan sentuhan, elakkan perbincangan topik tentang dirinya, mengingkari perubahan pada dirinya dan terlibat tingkah laku negatif seperti penggunaan ubat-ubatan, alkohol dan kurang bertanggungjawab.

Menurut Potter (2005) konsep diri merupakan kerangka acuan yang mempengaruhi pemikiran kita terhadap situasi dan hubungan kita dengan orang lain. Ketidaksesuaian antara aspek tertentu dari keperibadian dan konsep diri dapat menjadi sumber stres atau konflik. Menurut Talib, Mohd Shafie, Ahmad dan Tamuri (2014) pelajar boleh dibantu untuk mempunyai konsep kendiri akademik, konsep kendiri bukan akademik dan mempunyai motivasi pencapaian yang lebih baik. Pelbagai aktiviti dan program yang bersesuaian boleh dilaksanakan untuk meningkatkan tahap konsep kendiri dan motivasi pencapaian. Hasil daripada kajian yang dilakukan didapati tiada perbezaan signifikan dari segi jantina antara aspek konsep kendiri akademik, konsep kendiri bukan akademik dan motivasi pencapaian. 
Menurut Marsh (1990) konsep kendiri bukan akademik meliputi aspek emosi, perhubungan keluarga, rakan sebaya, keyakinan diri, penilaian diri, fizikal, perasaan terhadap diri sendiri dan identiti. Konsep kendiri akademik pula adalah persepsi seseorang mengenai diri sendiri yang berkaitan dengan institusi pendidikan (Burns, 1981). Menurut Zahara (2000), konsep kendiri yang positif dan motivasi pencapaian mempunyai signifikan dengan kecemerlangan akademik seseorang. Yahaya (2005) berpendapat bahawa semua pihak terutamanya pendidik bertanggungjawab untuk membimbing pelajar supaya memiliki konsep kendiri yang baik, mempunyai minda kelas pertama dan berketerampilan dalam pelbagai aspek.

Faizan et al. (2016) telah menjalankan kajian yang bertujuan untuk mengkaji hubungan konsep kendiri dan motivasi dengan pencapaian pelajar. Seramai 153 pelajar semester dua di Politeknik Tuanku Sultanah Bahiyah telah dijadikan sampel. Hasil daripada kajian ini menunjukkan bahawa terdapat perbezaan yang signifikan dari segi konsep motivasi berdasarkan jantina. Dapatan kajian juga menunjukkan bahawa pelajar mempunyai konsep kendiri bukan akademik yang baik yang dianggap dapat membantu dalam proses pengajaran dan pembelajaran. Menurutnya juga, pelajar sering bersedia dalam menghadapi penilaian yang berterusan, bermotivasi dan mempunyai keyakinan

tinggi dalam membuat keputusan.

Dalam kajian yang dilakukan oleh Mohd dan Shahizan (2016), mereka mendapati bahawa apabila tahap penghargaan kendiri meningkat, ia akan meningkatkan lagi tahap kepuasan hidup remaja dan apabila tahap penghargaan kendiri rendah, tahap kepuasan hidup juga akan rendah. Menurut penyelidik, aspek penghargaan kendiri perlu diberi perhatian serius dalam proses pembelajaran. Selain itu, dapatan kajian juga menyatakan bahawa rakan menjadi penyumbang yang paling dominan kepada kepuasan hidup. Remaja yang diberi kasih sayang sepenuhnya oleh ahli keluarga akan rasa dihargai dan disayangi sekali gus meningkatkan lagi kepercayaan diri individu. Analisis data juga mendapati bahawa guru-guru memainkan peranan dengan mencorakkan gaya pembelajaran, member pujian dan sokongan dapat menambahkan penghargaan kendiri remaja dalam proses pembelajaran.

Naam (2009) juga telah menjalankan kajian mengenai hubungan konsep diri dengan prestasi akademik dalam kalangan mahasiswa. Menurut pengkaji, cara individu memandang diri sendiri mempunyai peranan penting pada aspek psikologinya. Pandangan yang positif terhadap diri, penerimaan diri dan bersyukur dengan bahagian tubuh akan memberi rasa gembira dan meningkatkan keinginan untuk lebih berhasil dalam kehidupan. Pelajar yang mempunyai gambaran diri yang negatif akan membuat individu kehilangan jati diri serta merugikan kemampuan yang dimilikinya. Pelajar yang dikaji dalam kajian ini kebanyakannya memiliki konsep kendiri yang positif $(n=43 ; 86 \%)$. Jelas terbukti kesedaran pelajar terhadap diri sendiri cukup tinggi.

\section{Gaya Pembelajaran}

Gaya pembelajaran secara umumnya merujuk kepada cara atau stail pembelajaran seseorang individu. Dalam konteks psikologi pendidikan, gaya pembelajaran adalah bagaimana seseorang pelajar memberi tumpuan dan tindakan untuk memproses dan memperoleh maklumat, ilmu atau pengalaman yang baru. Di samping itu, gaya pembelajaran melibatkan suatu perancangan dalam sistem belajar iaitu cara membuat nota, cara susun bahan pembelajaran penting, cara ulang kaji isi dan tajuk pelajaran, dan penyiapan tugasan secara sistematik atau sebaliknya. Gaya pembelajaran juga dirujuk sebagai cara individu memproses serta mengekalkan maklumat dan pengetahuan baru (Dunn \& Dunn, 1979).

Melalui kajian yang dibuat oleh Wulandari (2011) dalam tajuk 'Hubungan Gaya Belajar dengan Prestasi Belajar Mahasiswa Semester IV Program Study D IV Kebidanan Universitas Sebelas Market' didapati pola gaya pembelajaran visual $(43.1 \%)$ adalah yang paling dominan yang diamalkan oleh responden dan diikuti oleh gaya belajar auditori (22.4\%) dan gaya pembelajaran kinestetik (13.8\%). Hasil kajian juga mendapati bahawa terdapat 12 responden yang memiliki lebih dari satu gaya pembelajaran iaitu 4 responden $(6.9 \%)$ memiliki gaya pembelajaran visual-auditori, 4 responden (6.9\%) memiliki gaya pembelajaran auditori-kinestetik dan 4 responden (6.9\%) visual-kinestetik. Selain itu, terdapat perhubungan di antara gaya pembelajaran dengan prestasi pembelajaran. 
Menurutnya, apabila responden tahu gaya pembelajaran dan guna cara yang sesuai dengan gaya gaya pembelajaran, maka akan peroleh prestasi yang lebih baik.

Memetik hasil kajian oleh Norlia et.al.(2006) melaporkan bahawa jika gaya pembelajaran yang diamalkan itu sesuai, maka dapat membantu pelajar memperoleh pencapaian yang tinggi. Daripada hasil kajian, didapati bahawa terdapat perhubungan antara gaya pembelajaran pelajar dengan motivasi. Beliau melaporkan bahawa skor min tertinggi adalah gaya permukaan (44.44) dan gaya mendalam (44.23), diikuti gaya terancang (31.50) dan akhir sekali gaya gigih usaha (29.13). Ini bermaksud, majoriti pelajar mengamalkan gaya dorongan, gaya permukaan dan gaya mendalam berbanding dengan gaya gigih usaha dan gaya terancang. Berdasarkan perbincangannya, kesemua maklumat tentang gaya pembelajaran dapat membantu guru mengenal pasti gaya pembelajaran pelajar agar apa yang diajar dapat penuhi perbezaan setiap individu.

Dalam kajian yang telah dilakukan oleh Rijal \& Bachtiar (2015) mereka mendapati bahawa setiap orang akan menggunakan ketiga-tiga gaya pembelajaran pada tahap tertentu, tetapi salah satu daripada tiga ini akan lebih cenderung untuk menonjol. Menurutnya juga, setiap cara mengajar bergantung dengan gaya seseorang itu belajar, peribadinya dan keinginannya. Guru-guru haruslah perhatikan gaya belajar melalui cara interaksi semasa proses pembelajaran. Analisis data juga mendapati bahawa gaya pembelajaran yang mendominasi adalah gaya pembelajaran visual diikuti auditori dan kinestetik. Kecenderungan responden dalam proses pembelajaran menitikberatkan ketajaman penglihatan. Organ penglihatan adalah lebih cepat dalam menerima informasi berbanding organ pendengaran dan penggerakan.

Gokalp (2013) telah melakukan penyelidikan mengenai kesan gaya pembelajaran pelajar terhadap kejayaan akademik. Dalam kajian ini, 140 mahasiswa di Ondokus Mayis Universiti, turkey telah dipilih sebagai sampel. Melalui kajian yang dijalankan, didapati terdapat perhubungan positif antara skor pasca ujian dan pra ujian. Pelajar yang tidak mempunyai perancangan pelajaran atau tidak dapat mengikuti rancangan mereka pada permulaan didapati untuk mempunyai program pembelajaran yang terancang pada akhir masa. Menurut beliau, program harus dirancang dengan sebaiknya untuk meningkatkan gaya pembelajaran bagi semua peringkat supaya proses pembelajaran dan pengajaran jadi lebih efektif. Selain itu, katanya reka bentuk program juga harus fleksibel supaya dapat mencapai pelbagai gaya pembelajaran.

Penemuan penyelidik menunjukkan bahawa setiap pelajar akan belajar dengan lebih banyak apabila mereka menyedari gaya pembelajaran mereka dan penentuan ini dapat membantu guru dan ibu bapa dalam menyediakan sokongan sosial dan bekalan pendidikan kepada pelajar (O'Connor, 1997). Dalam kajian yang dilakukan oleh Ghaedi dan Jam(2014) berkaitan tiga gaya pembelajaran dalam kalangan pelajar, strategi sosial, motivasi pelajar dalam pembelajaran dan perkaitan antara kedua-duanya. Menurutnya, perbezaan variabel individu seperti kecerdasan, personaliti dan minat vokasional boleh digunakan untuk menjelaskan bukan hanya dapat pelbagaikan dalam prestasi akademik tetapi juga ciri-ciri yang secara tidak langsung dapat mempengaruhi keputusan peperiksaan.

\section{Model Gaya Pembelajaran VAK}

Menurut O'Brien (1990), beliau menekankan gaya pembelajaran visual, auditori dan kinestetik. Menurutnya, pentingnya nilai dalam samakan gaya pembelajaran pelajar dengan arahan yang sesuai. Pelajar harus sedar tentang gaya pembelajaran mereka dan bagaimana ia berkait dengan cara mereka belajar dan mengambil ujian. Model VAK ini memberi perspektif yang berbeza untuk memahami dan menerangkan gaya pembelajaran yang dominan dan kekuatannya.

Gaya pembelajaran auditori adalah pelajar yang lebih cenderung kepada deria pendengaran. Pelajar auditori ini akan belajar dengan dengar perkataan yang disebut. Mereka menggunakan teknik bercerita sebagai alat pembelajaran. Contohnya, mereka akan mendengar dahulu pengajaran yang diberi oleh guru sebelum membaca nota yang diberikan, menggunakan pita rakaman dan menggunakan komputer. Penerangan tentang sesuatu lebih mudah diingati apabila membaca dengan kuat atau mengerakkan bibir ketika membaca. Untuk mengingati kembali apa yang dibaca, mereka akan mendengar rakaman 
audio, terangkan dan berbincang dengan rakan. Mereka lebih menyukai muzik dan semua jenis bunyi terutamanya yang menarik seperti puisi, irama dan perkataan yang diucapkan. Aktiviti yang disarankan buat pelajar auditori adalah menghadiri kuliah, perbincangan, rakaman, permainan dan temuduga. Pembelajaran auditori mengekalkan pengetahuan yang terbaik melalui maklumat pendengaran dan bukannya melihatnya.

Gaya pembelajaran visual adalah pelajar yang belajar melalui deria dan aktiviti penglihatan. Gaya pembelajaran ini adalah kecenderungan terhadap imej, warna, graf, gambar, peta, teks berbentuk perkataan dan lain-lain. Dengan kata lain, pelajar gaya pembelajaran visual ini mahukan sesuatu yang dapat memikat mata mereka. Informasi akan diproses dan difahami dengan lebih cepat apabila maklumat dibentangkan di hadapan mereka. Sebagai contoh, pelajar akan lebih mengingati dan memahami penerangan melalui pembacaan ayat atau teks. Pelajar gaya ini akan menulis nota yang diberi oleh guru dan mereka akan menggunakan pen warna untuk menekankan dan membezakan sesuatu fakta. Teknik menulis nota syarahan dan arahan lisan juga akan digunakan jika ingin mengingati selalu.

Gaya pembelajaran kinestetik adalah pelajar yang belajar melalui pergerakan badan, pembuatan dan sentuhan. Mereka mempunyai kemahiran psikomotor yang hebat. Mereka belajar melalui sesuatu dan lebih suka untuk belajar melalui pengalaman praktikal dan hadirkan diri secara fizikal dalam aktiviti kelas. Pelajar ini mudah terganggu, jadi guru-guru haruslah sediakan aktiviti yang mengharuskan penglibatan secara aktif dan sentiasa fokuskan mereka.

\section{Motivasi Akademik}

Mohamadi (2006) menyatakan bahawa motivasi dipengaruhi oleh empat faktor iaitu persekitaran, keadaan dalaman sesuatu, matlamat tingkah laku, tujuan dan kecenderungan dan instrumen bagi mencapai matlamat. Bagi mencapai sesuatu matlamat dan keperluan, seseorang itu memerlukan motivasi yang mencukupi. Khususnya bagi pelajar, motivasi akademik adalah sesuatu yang sangat penting kerana dengan motivasi itu pelajar-pelajar akan dirangsang untuk berjaya menyempurnakan tugasan, mencapai matlamat atau mendapat ijazah kelayakan dalam profesion mereka. Dalam perspektif pendidikan, motivasi mempunyai struktur pelbagai dimensi yang saling berkait dengan pembelajaran dan motivasi akademik.

Menurut National Association of School Psychologists (2014), individu yang memiliki motivasi akademik yang negatif tidak akan dapat berfungsi dengan baik dalam tugasan sekolah yang diberi dan tidak akan mencuba dengan betul-betul kerana mereka memikirkan ia tidak akan membawa apa-apa perbezaan. Terdapat beberapa sebab yang mungkin merendahkan motivasi akademik seseorang iaitu ciri-ciri pelajar, kegagalan sebelum ini,sikap rakan dan ibu bapa serta perlumbaan yang sengit dalam akademik. Manakala, individu yang memiliki motivasi akademik yang positif akan sentiasa menunjukkan keinginan yang tinggi untuk belajar, percaya bahawa sekolah penting dan amat menyukai segala kegiatan belajar yang berkait. Menurutnya juga, motivasi akademik sangatlah penting dalam semua aspek kehidupan akademik, pekerjaan dan masyarakat dan membantu individu melihat pembelajaran yang bermanfaat.

Iredho (2015) telah mengkaji hubungan antara motivasi akademik dengan prokrastinasi akademik. 30 pelajar pascasiswazah di sebuah sekolah di Jakarta telah menjadi responden. Beliau mendapati motivasi akademik tidak dapat menurunkan prokrastinasi akademik Daripada analisis yang telah dilakukan berdasarkan kajian ini, beberapa konklusi telah dibuat. Pertama, tiada hubungan antara motivasi akademik dengan prokastinasi akademik dan terdapat beberapa faktor lain yang lebih dominan di mana mempengaruhi perilaku prokastinasi akademik. Selain itu, dalam bidang akademik, prokrastinasi secara tak langsung dapat merosakkan prestasi akademik, menyebabkan rendahnya motivasi pada pelajar dan menurunkan kepercayaan diri pelajar.

Dalam kajian yang dilakukan oleh Cayubit et.al.(2012), mereka mendapati bahawa pelajar yang mempunyai latar belakang pendidikan adalah kurang didorong dengan cabaran-cabaran tugasan akademik. Sebaliknya, punca utama mereka mencapai gred tinggi adalah kerana mereka belajar. 
Pelajar yang mempunyai latar belakang pendidikan lebih cenderung untuk memperoleh skor min yang lebih rendah dalam skala Efisien Kendiri. Mereka percaya bahawa diri mereka tidak mampu untuk melakukan tugas-tugas akademik yang mencabar dan tugasan baru dengan sendiri. Individu yang kurang berusaha tidak akan bermotivasi secara intrinsik. Hasil daripada kajian mendapati bahawa kumpulan latar belakang pendidikan dan tiada latar belakang pendidikan mempunyai perbezaan yang ketara pada komponen motivasi akademik intrinsik dan efisien Kendiri. Pelajar yang tiada latar belakang pendidikan adalah cenderung untuk lebih bermotivasi secara intrinsik berbanding mereka yang telah ada latar belakang pendidikan.

\section{Perhubungan Konsep Kendiri dengan Motivasi Akademik}

Motivasi akademik adalah sesuatu keperluan yang berkait rapat dengan konsep kendiri seorang mahasiswa. Seorang pelajar yang berjaya akan tahu dan sedar akan tanggungjawab mereka terhadap kemajuan diri kerana mereka tahu bahawa kunci penggerak itu ada pada diri dan pelajar yang sering abaikan peranan motivasi sering dikaitkan dengan kegagalan. Seorang pelajar harus belajar untuk terima diri seadanya berikutan dari aspek penerimaan terhadap kegagalan yang pernah dilalui.

Menurut Maulida \& Dhania (2012) dalam kajiannya bertajuk 'Hubungan antara Kepercayaan Diri dan Dukungan Orang Tua dengan motivasi berwirausaha pada siswa SMK' mendapati bahawa semakin tinggi kepercayaan diri yang dimiliki maka semakin tinggi motivasi berwirausaha pada siswa. Berdasarkan hasil kajiannya terdapat perhubungan positif yang signifikan antara motivasi berwirausaha dengan kepercayaan diri iaitu $0.438(\mathrm{p}<0.01)$. Menurut mereka, kepercayaan diri akan berpengaruh pada gagasan, inisiatif, kreativiti, keberanian, ketekunan, semangat kerja keras dan keghairahan berkarya seseorang individu.

Menurutnya, seseorang haruslah percaya kepada kemampuan sendiri, bertindak sendiri dalam mengambil keputusan, memiliki rasa positif yang ada pada diri sendiri dan berani meluahkan pendapat serta sentiasa menjadi motor penggerak dalam kegiatan yang dilaksanakan. Memetik hasil kajian oleh Prabadewi dan Widiasavitri (2014) melaporkan bahawa konsep kendiri akademik dan motivasi saling berkorelasi secara signifikan dan positif. Semakin positif konsep kendiri akademik maka semakin tinggi motivasi yang dimiliki remaja. Menurutnya, konsep kendiri adalah dasar untuk semua perilaku yang bermotivasi di mana konsep kendiri sentiasa menjadikan diri ideal yang dapat ciptakan motivasi dalam tingkah laku seseorang. Apabila individu menerima diri dengan positif, maka individu tersebut akan menjadi optimis dengan usahanya supaya dapat berjaya. Menurut Djamarah (2011), motivasi berprestasi adalah daya penggerak yang sentiasa memberi semangat bekerja seseorang, mendorong untuk kembangkan kreativiti dan maksimumkan kemampuan demi mencapai prestasi maksimum.

Yahaya (2005) juga telah menjalankan kajian mengenai hubungan antara konsep kendiri,motivasi dan gaya keibubapaan dengan pencapaian pelajar. Menurut pengkaji, cara interaksi antara ibu bapa dan anak-anak, menilai dan hargai anak-anak sebenarnya memberi kesan mendalam pada pembentukan konsep kendiri anak-anak dan semangat mereka dalam melakukan sesuatu. Dapatan kajian menunjukkan bahawa kebanyakan pelajar memiliki tahap konsep kendiri akademik yang tinggi manakala motivasi yang dominan adalah motivasi ekstrinsik. Daripada analisis hasil kajian oleh responden, didapati faktor-faktor motivasi ekstrinsik dan intrinsik mempengaruhi motivasi mereka.

\section{Perhubungan Gaya Pembelajaran dengan Motivasi Akademik}

Setiap orang berkemungkinan untuk mempunyai lebih dari satu jenis gaya pembelajaran. Gaya pembelajaran seseorang individu berkemungkinan bersifat dinamis di mana ia boleh berubah. Dengan memiliki gaya pembelajaran yang betul dapat membantu pelajar dalam pembelajaran mereka. Misalnya, pelajar akan rasa teruja apabila mendapat gred yang cemerlang. Jadi, secara tak langsung ia dapat meningkatkan motivasi pelajar dan ingin melakukan dengan lebih baik lagi. Guru-guru haruslah peka bahawa pelajar mempunyai gaya pembelajaran yang berbeza, jadi mereka haruslah kenal pasti cara pengajaran yang sesuai dengan gaya pembelajaran pelajar. Maka, dengan ini pelajar akan mempunyai persepsi bahawa mereka berkebolehan. 
Kajian yang bertajuk 'Hubungan antara Gaya Pembelajaran dengan Motivasi dalam Kalangan Pelajar di Sebuah Sekolah Menengah Luar Bandar, Sabah' oleh Rashid (2007) menunjukkan gaya pembelajaran yang paling dominan yang diamalkan adalah auditori (min 3.81, SP $=0.91$ ) diikuti kategori kinestetik ( $\min 3.77, \mathrm{SP}=0.98)$ dan visual $(\min 3.43, \mathrm{SP}=0.97)$. Dalam kajian ini, terdapat perhubungan yang signifikan pada aras signifikan $\alpha=0.05$ antara gaya pembelajaran pelajar dengan motivasi. Bagi tahap motivasi kategori motivasi intrinsik menunjukkan pelajar bermotivasi sederhana, manakala bagi motivasi ekstrinsik menunjukkan pelajar bermotivasi sederhana. Hasil kajian juga mendapati bahawa ada perhubungan antara gaya pembelajaran kinestetik dengan motivasi ekstrinsik dan intrinsik dan tiada perhubungan antara gaya pembelajaran auditori dan visual dengan motivasi ekstrinsik dan intrinsik.

Memetik hasil kajian oleh Sulaiman dan Jasmi (2013) melaporkan bahawa pelajar akan menghadapi konflik dalam belajar apabila tidak menggunakan gaya pembelajaran yang sesuai. Misalnya, apabila aktiviti dan gaya pengajaran guru tidak selari dengan gaya pembelajaran pelajar, maka ia akan menimbulkan konflik. Pelajar akan kurang minat dan tidak dapat tumpukan perhatian dan hal ini menyebabkan pelajar mendapat markah yang kurang memuaskan Secara perlahan-lahan, hal ini akan menyebabkan minat dalam diri pelajar berkurangan dan akhirnya pelajar berputus asa.

Berdasarkan kajian oleh Ramos et al. (2012), responden dibahagikan kepada dua kumpulan iaitu kepada ada pendedahan pendidikan dan tiada pendidikan. Hasil kajian mendapati terdapat perbezaan yang signifikan dalam motivasi akademik intrinsik dan keberkesanan kendiri di mana pelajar dengan pendedahan pendidikan dapat rendah. Menurutnya, pelajar yang tidak mempunyai pendedahan kepada pendidikan lebih bermotivasi secara intrinsik berbanding mereka yang ada pendidikan. Analisis dari responden mendapati bahawa tahap keyakinan yang lebih rendah adalah mungkin kerana kekurangan peluang untuk belajar dan cari penyelesaian dan berlatih secara bebas. Pelajar yang tidak mempunyai pendedahan pendidikan digambarkan mempunyai efikasi diri yang lebih tinggi berbanding yang lain. Hasil kajian mendapati bahawa perbezaan gaya pembelajaran dengan kedua-dua kumpulan itu tidak signifikan, $\mathrm{X} 2(\mathrm{~N}=138)=5.82, \mathrm{p}>0.05$.

\section{Kaedah Kajian}

\section{Reka Bentuk Kajian}

Dalam kajian ini, pendekatan kuantitatif digunakan untuk menyelesaikan masalah dan menjawab objektif yang dibangunkan. Kajian ini dijalankan menggunakan pendekatan deskriptif melalui kaji selidik untuk menentukan tahap konsep kendiri, gaya pembelajaran dan jenis motivasi akademik dalam kalangan responden. Kajian berbentuk kepustakaan juga dibuat berdasarkan maklumat yang diperoleh daripada bahan-bahan seperti majalah, jurnal,buku dan kertas kerja. Kajian lapangan juga dilaksanakan bagi memperoleh data primer yang mana juga merupakan data asli mengenai maklumat individu. Kajian berbentuk korelasi juga digunakan untuk menerangkan perhubungan antara angkubah dan juga perubahan dalam satu angkubah akan pengaruhi angkubah lain.

\section{Lokasi Kajian}

Universiti Putra Malaysia di Selangor telah dipilih sebagai lokasi kajian kerana Selangor merupakan bandar utama di Malaysia. Jadi, terdapat banyak gangguan dari segi hiburan di negeri Selangor. Tuntasnya, pelajar pada hari ini merupakan aset negara pada masa akan datang kerana tenaga dan fikiran anak muda pada hari ini akan digunakan untuk pembangunan negara ke arah mencapai status negara maju suatu hari nanti.

\section{Populasi Kajian}

Populasi kajian terdiri daripada mahasiswa tahun pertama di Universiti Putra Malaysia yang mempunyai pelbagai latar belakang. Jumlah keseluruhan mahasiswa tahun pertama di Universiti Putra Malaysia seramai $\mathrm{N}=3594$ (sumber: Bahagian Pengurusan Akademik UPM, Selangor, tahun 
2019/2020). Kajian ini dijalankan ke atas mahasiswa tahun pertama kerana pelajar mahasiswa tersebut sedang berhadapan dengan peralihan dari kehidupan zaman matrikulasi, asasi ataupun diploma kepada dunia yang baru.

\section{SampelKajian}

Sampel adalah kumpulan kecil daripada populasi yang menjadi sasaran penyelidik untuk melakukan penyelidikan. Jadual Kreichie dan Morgan digunakan untuk menentukan saiz sampel bagi populasi UPM. Berdasarkan persamplen Krejce Morgan, saiz sampel adalah 351 responden. Bagi mencapai objektif kajian, pengkaji telah membahagikan jumlah sampel ini mengikut taburan jantina mahasiswa tahun pertama.

Persampelan rawak berstrata telah digunakan. Persampelan ini digunakan apabila terdapat dua kumpulan yang tidak dapat mewakili bilangan yang sama dengan sampel. Ia adalah teknik di mana melibatkan pembahagian populasi ke kumpulan yang lebih kecil yang dikenali sebagai strata. Sampel dibahagikan mengikut kuota yang ditentukan iaitu jantina. Teknik ini mempunyai kelebihan di mana dapat memberi perwakilan yang tinggi untuk setiap strata.

Pertama, Universiti Putra Malaysia dipilih. Kemudian, populasi mahasiswa itu telah distratakan mengikut jantina lelaki dan perempuan. Kebenaran telah didapatkan dari pihak pengurusan untuk proses mengedarkan borang soal selidik. Data telah dikutip menggunakan borang soal selidik. 351 responden telah dipilih untuk menjawab borang soal selidik di UPM. Populasi perempuan adalah lebih dari populasi lelaki. Jadi, nisbah perempuan kepada lelaki adalah 2:1, iaitu 234: 117 .

\section{Instrumentasi}

Borang soal selidik berbentuk soalan tertutup diagihkan kepada responden. Terdapat empat (4) bahagian dalam borang soal selidik ini.

\section{Bahagian A: Latar belakang responden}

Bahagian A merangkumi soalan berkenaan latar belakang responden yang terdiri daripada tujuh (7) item. Item pertama umur, diikuti item kedua PNGK, item ketiga jantina, item keempat bangsa, item kelima agama, item keenam jumlah adik beradik dan item ketujuh pendapatan keluarga responden.

\section{Bahagian B: Konsep Kendiri}

Konsep kendiri responden diukur dengan mengadaptasi borang soal selidik dari Faizan, Nur \& Azlina (2016). Skala likert yang digunakan adalah skala likert 5 mata, 1- Tidak Benar Sama Sekali, 2- Tidak Benar, 3- Tidak Pasti, 4- Benar, 5- Benar Sama Sekali. Kaedah analisis yang digunakan adalah Skor Min, Sisihan Piawai, peratusan min dan frekuensi. Dalam kajian ini, borang soal selidik yang digunakan mengandungi 1 item dan 30 sub item. Skala likert yang digunakan adalah skala likert 3 mata, 1- Tidak Setuju, 2- Tidak Pasti, 3- Setuju. Kaedah analisis yang digunakan adalah Skor Min, Sisihan Piawai, peratusan min dan frekuensi.

Jadual 1: Ringkasan konsep kendiri

\begin{tabular}{ll}
\hline Adaptasi & Soal selidik asal \\
\hline Konsep Kendiri & Konsep Kendiri \\
1 item & 2 item \\
30 sub item & 15 sub item \\
Kaedah analisis skor min, sisihan piawai, & Kaedah analisis skor min, sisihan piawai, \\
peratusan min, frekuensi & peratusan min, frekuensi \\
Skala likert 3 mata & Skala likert 5 mata \\
\hline
\end{tabular}




\section{Bahagian C: Gaya pembelajaran}

Gaya pembelajaran responden diukur dengan menggunakan satu set soal selidik yang telah direka oleh O’Brien (1985) iaitu 'Learning Channel Preference'. Soal selidik ini mengandungi 3 item dan mempunyai 10 sub item. Skala likert yang digunakan adalah skala likert 3 mata, 1- Tidak Pernah, 2Kadang-Kadang, 3- Selalu.Dalam kajian ini, borang soal selidik yang digunakan mengandungi 3 item dan 10 sub item yang terdiri daripada gaya pembelajaran visual, auditori dan kinestetik. Skala likert yang digunakan adalah skala likert 3 mata, 1- Tidak Pernah, 2- Kadang-Kadang, 3- Selalu. Kaedah analisis yang digunakan adalah taburan frekuensi, peratusan, hubungan korelasi, ujian parametrik (Ttest).

Jadual 2: Ringkasan konsep kendiri

\begin{tabular}{ll}
\hline Adaptasi & Soal selidik asal \\
\hline Gaya Pembelajaran & Learning Channel Preference \\
3 item & 3 item \\
10 sub item & 10 sub item \\
Kaedah analisis frekuensi, peratusan, & Skala likert 3 mata \\
hubungan korelasi, ujian parameter (T-test). & \\
Skala likert 3 mata & \\
\hline
\end{tabular}

\section{Bahagian D: Motivasi Akademik}

Motivasi akademik responden diukur dengan diadaptasi dari soal selidik Britt \& Gorill (2016). Skala likert yang digunakan adalah skala likert 7 mata, 1- Sangat setuju, 2- Setuju, 3- Agak setuju, 4Neutral, 5- Agak tidak setuju, 6- Tidak setuju, 7- Sangat tidak setuju. Kaedah analisis yang digunakan adalah Skor Min, Sisihan Piawai, peratusan min, frekuensi, korelasi, skewness, kurtosis dan alpha. Dalam kajian ini, borang soal selidik yang digunakan mengandungi 7 item dan mempunyai 4sub item. Skala likert yang digunakan adalah skala likert 3 mata, 1- Tidak Setuju, 2- Tidak Pasti, 3- Setuju. Kaedah analisis yang digunakan adalah Skor Min, Sisihan Piawai, peratusan min, frekuensi, korelasi dan alpha.

Jadual 3: Ringkasan konsep kendiri

\begin{tabular}{ll}
\hline Adaptasi & Soal selidik asal \\
\hline Motivasi Akademik & Academic Motivation \\
7 item & 7 item \\
4 sub item & 4 sub item \\
Kaedah analisis skor min, sisihan piawai, & Kaedah analisis skor min, sisihan piawai, \\
peratusan min, frekuensi, korelasi dan alpha & peratusan min, frekuensi, korelasi, skewness, \\
Skala likert 3 mata & kurtosis dan alpha \\
& Skala likert 7 mata \\
\hline
\end{tabular}

\section{Kajian Rintis}

Sebelum data sebenar dikumpulkan, kesemua skala telah diuji dalam kajian rintis untuk memeriksa kebolehpercayaan dan kesahan instrumen yang digunakan. Instrumen kajian telah diuji dalam kalangan 20 orang mahasiswa tahun pertama sesi 2018/2019 di Universiti Putra Malaysia. Dengan ini, segala penambahbaikan soal selidik dapat dilakukan sebelum diedarkan kepada responden. Hasil daripada kajian rintis dianalisis menggunakan perisian Statistical Package for Social Science (SPSS) untuk melihat pekali kebolehpercayaan. Kebolehpercayaan dalaman item diuji dengan mengira pekali Alpha. Pekali Alpha bertujuan untuk menentukan konsistensi dalaman atau purata korelasi bagi item sebuah soal kaji selidik untuk menguji kebolehpercayaan. Semakin tinggi skor semakin tinggi kemungkinannya bagi skala untuk dijana. Hasil daripada kajian rintis didapati bahawa secara keseluruhannya nilai pekali Alpha untuk borang soal selidik Konsep Kendiri adalah 0832. Seterusnya, nilai pekali Alpha buat borang soal selidik Gaya Pembelajaran adalah 0.711. Akhir sekali, nilai pekali 
DOI: https://doi.org/10.47405/mjssh.v6i2.683

Alpha buat borang soal selidik Motivasi Akademik adalah 0.705. Secara keseluruhannya, nilai pekali Alpha untuk kajian rintis ini adalah lebih tinggi dari 0.7. Jadi, skala dikatakan mempunyai kebolehpercayaan yang mencukupi.

Jadual 4: Analisis Kebolehpercayaan

\begin{tabular}{lll}
\hline Borang Soal Selidik & No. Item & Pekali Alpha $(\mathbf{n}=20)$ \\
Soal Selidik Konsep Kendiri & 30 & 0.832 \\
Soal Selidik Gaya Pembelajaran & 30 & 0.711 \\
Soal Selidik Motivasi Akademik & 28 & 0.705 \\
\hline
\end{tabular}

\section{Pengumpulan Data}

Bagi proses pengumpulan data, data-data yang diperoleh adalah daripada sumber primer iaitu data yang diperoleh daripada mahasiswa tahun pertama di Universiti Putra Malaysia. Kajian ini adalah penyelidikan kuantitatif dengan menggunakan borang soal selidik dan soal selidik dalam talian sebagai kaedah kaji selidik. Borang soal selidik telah diagihkan kepada kumpulan sasaran. Pengumpulan data bertujuan untuk mendapat maklumat responden tentang kajian yang ingin dijalankan.

Responden harus melengkapkan borang soal selidik mengikut arahan yang telah dinyatakan. Borang soal selidik telah dibuat dengan bahasa Melayu dan mempunyai empat bahagian yang mana menggunakan tiga instrumen di mana dua instrumen adalah angkubah bebas dan satu instrumen adalah angkubah bersandar. Pada bahagian A, responden dikehendaki untuk mengisi butiran peribadi seperti umur, PNGK, jantina, bangsa, agama, jumlah adik beradik dan pendapatan keluarga.

Konsep kendiri diukur di bahagian B diikuti gaya pembelajaran diukur di bahagian $\mathrm{C}$ dan motivasi akademik diukur di bahagian D. Setelah selesai mengutip data, data diproses dan dianalisis. Secara keseluruhan, proses pengumpulan data ini mengambil masa selama lebih kurang dua bulan bermula 7 Jun 2019 hingga 5 Ogos 2019.

\section{Penganalisisan Data}

Penganalisisan data adalah satu cara untuk mengolah data menjadi informasi supaya ciri-ciri data tersebut dapat difahami dan bermanfaat untuk selesaikan masalah yang berkaitan dengan kajian. Data akan dianalisis menggunakan perisian Statistical Package for Social Science (SPSS). Kesemua data statistik telah melalui analisis deskriptif pada tahap analisis univariate dan analisis bivariat. Deskriptif analisis untuk terangkan tentang data yang didapati. Pada bivariate analysis, T-Test dan korelasi Pearson digunakan. Hasil analisis terdiri daripada jumlah, peratus, purata, sisihan piawai, nilai maksimum dan minimum. Univariate analisis bertujuan untuk memerihalkan ciri demografi responden, tahap konsep kendiri, gaya pembelajaran dan motivasi akademik seperti objektif khusus 1 , 2 dan 4.

Perhubungan antara angkubah bebas dan angkubah bersandar akan diuji menggunakan Pearson Correlation. Penggunaan bivariate analysis bertujuan untuk menguji perkaitan antara angkubah bebas dengan angkubah bersandar dengan guna analisis Pearson Correlation. Hasil analisis adalah untuk melihat perkaitan antara konsep kendiri dan gaya pembelajaran dengan motivasi akademik. T-Test digunakan untuk menguji perhubungan antara jantina seperti dinyatakan di objektif khusus 4.

\section{Jadual 5: Ringkasan Objektif}

\begin{tabular}{lll}
\hline Objektif & Bahagian & Kaedah \\
\hline $\begin{array}{l}\text { Objektif 1: Untuk memerihalkan latar belakang } \\
\text { responden yang terlibat dalam kajian ini. }\end{array}$ & $\mathrm{A}$ & Univariate analysis \\
$\begin{array}{l}\text { Objektif 2: Untuk mengukur tahap konsep kendiri, } \\
\text { gaya pembelajaran dan motivasi akademik dalam } \\
\text { kalangan mahasiswa tahun pertama }\end{array}$ & $\mathrm{B}, \mathrm{C}, \mathrm{D}$ & Univariate analysis \\
\hline
\end{tabular}




\begin{tabular}{lll}
\hline $\begin{array}{l}\text { Objektif 3: Untuk mengkaji perhubungan antara } \\
\text { konsep kendiri dan gaya pembelajaran dengan } \\
\text { motivasi akademik dalam kalangan mahasiswa }\end{array}$ & B dan D & $\begin{array}{l}\text { Bivariate analysis, } \\
\text { Pearson Correlation }\end{array}$ \\
$\begin{array}{l}\text { tahun pertama } \\
\begin{array}{l}\text { Objektif 4: Untuk mengkaji perbezaan konsep } \\
\text { kendiri, gaya pembelajaran dan motivasi } \\
\text { akademik dalam kalangan mahasiswa tahun } \\
\text { pertama antara lelaki dan perempuan. }\end{array}\end{array}$ & B, C, D & $\begin{array}{l}\text { Univariate analysis, } \\
\text { Bivariate analysis }\end{array}$ \\
\end{tabular}

\section{Dapatan Kajian}

\section{Analisis terhadap Latar Belakang Responden}

\section{a) Jantina}

Bilangan majoriti responden untuk kajian ini adalah perempuan dengan 243 (69.2\%) bilangan pelajar manakala lagi $108(30.8 \%)$ adalah pelajar lelaki.

Jadual 6: Taburan Responden mengikut Jantina

\begin{tabular}{lll}
\hline Jantina & Kekerapan & Peratusan (\%) \\
\hline Lelaki & 108 & 30.8 \\
Perempuan & 243 & 69.2 \\
Jumlah & 351 & 100 \\
\hline
\end{tabular}

\section{b) Umur}

Secara keseluruhannya, umur pelajar tahun pertama di Universiti Putra Malaysia adalah dalam lingkungan 18 hingga 22 tahun. Hasil kajian menunjukkan majoriti responden berumur 19 tahun dengan jumlah 196 (55.8\%) pelajar. Diikuti dengan responden berumur 20 tahun dengan jumlah 134 (38.2\%) pelajar, $12(3.4 \%)$ pelajar berumur 21 tahun, 6(1.7\%) pelajar berumur 22 tahun dan hanya 3 $(0.9 \%)$ pelajar berumur 18 tahun.

Jadual 7: Taburan Responden mengikut Umur

\begin{tabular}{lll}
\hline Jantina & Kekerapan & Peratusan (\%) \\
\hline 18 tahun & 3 & 0.9 \\
19 tahun & 196 & 55.8 \\
20 tahun & 134 & 38.2 \\
21 tahun & 12 & 3.4 \\
22 tahun & 6 & 1.7 \\
Jumlah & 351 & 100 \\
\hline
\end{tabular}

\section{c) Bangsa}

Berdasarkan Jadual 8, majoriti responden adalah berbangsa Melayu dengan jumlah seramai 277 (78.9) pelajar, diikuti dengan jumlah yang sama antara bangsa Cina dan India dengan $28(8.0 \%)$ pelajar. Pelajar yang memilih "Lain-lain" sebagai pilihan merangkumi pelajar Iban, Bidayuh dan Orang Asli.

Jadual 8: Taburan Responden mengikut Bangsa

\begin{tabular}{lll}
\hline Jantina & Kekerapan & Peratusan (\%) \\
\hline Melayu & 277 & 78.9 \\
\hline
\end{tabular}


DOI: https://doi.org/10.47405/mjssh.v6i2.683

\begin{tabular}{lll}
\hline Cina & 28 & 8.0 \\
India & 28 & 8.0 \\
Lain-lain & 18 & 5.1 \\
Jumlah & 351 & 100 \\
\hline
\end{tabular}

\section{d) Agama}

Berdasarkan Jadual 9, majoriti responden beragama Islam dengan jumlah 287 (81.8\%) pelajar. Diikuti dengan responden beragama Buddha dengan jumlah 29 (8.3\%) pelajar, 25 (7.1\%) pelajar beragama Hindu dan hanya $10(2.8 \%)$ pelajar beragama Kristian.

Jadual 9: Taburan Responden mengikut Agama

\begin{tabular}{lll}
\hline Jantina & Kekerapan & Peratusan (\%) \\
\hline Islam & 287 & 81.8 \\
Buddha & 29 & 8.3 \\
Hindu & 25 & 7.1 \\
Kristian & 10 & 2.8 \\
Jumlah & 351 & 100 \\
\hline
\end{tabular}

\section{e) Pendapatan Keluarga}

Berdasarkan Jadual 10, majoriti responden adalah dalam kalangan B40 iaitu kurang dari RM 3860 dengan jumlah 182 (51.9\%) pelajar, diikuti dengan pendapatan keluarga M40 iaitu dalam lingkungan RM 3860- RM 8319 dengan jumlah 97 (27.6\%) pelajar dan akhir sekaliT20 iaitu lebih dari RM8319 dengan jumlah $72(20.5 \%)$ pelajar.

Jadual 9: Taburan Responden mengikut Pendapatan Keluarga

\begin{tabular}{lll}
\hline Jantina & Kekerapan & Peratusan (\%) \\
\hline B40 (<RM3860.00) & 182 & 51.9 \\
M40 (RM3860.00-RM8319.00) & 97 & 27.6 \\
T20 (>RM8319) & 72 & 20.5 \\
Jumlah & 351 & 100 \\
\hline
\end{tabular}

\section{Analisis tahap Konsep Kendiri, Gaya Pembelajaran dan Motivasi Akademik dalam kalangan responden}

\section{Konsep Kendiri}

Tahap konsep kendiri dalam kalangan mahasiswa tahun pertama di Universiti Putra Malaysia (min= $2.366)$ berada pada tahap yang tinggi $(66.38 \%)$ dengan jumlah 233 pelajar. Seterusnya, tahap rendah bagi golongan mahasiswa tahun pertama terhadap konsep kendiri mendapat nilai sifar dan tahap sederhana dengan nilai 118 (33.61\%) pelajar memiliki tahap konsep kendiri yang sederhana. Dapat dikonklusikan majoriti pelajar tahun pertama Universiti Putra Malaysia mempunyai tahap konsep kendiri yang tingi dengan skor sum 70 hingga 90.

Jadual 10: Konsep Kendiri dalam kalangan Responden ( $\mathrm{N}=351)$

\begin{tabular}{lllll}
\hline Tahap Konsep Kendiri & Skala & Kekerapan & $\begin{array}{l}\text { Peratusan } \\
(\boldsymbol{\%})\end{array}$ & Min \\
\hline Rendah & $30-49$ & 0 & 0.00 & \\
Sederhana & $50-69$ & 118 & 33.61 & 2.366 \\
Tinggi & $70-90$ & 233 & 66.38 & \\
\hline
\end{tabular}




\section{Gaya Pembelajaran}

Skor min yang tinggi adalah gaya pembelajaran visual (2.203) dan gaya pembelajaran Kinestetik (2.198) dan diikuti dengan gaya pembelajaran terakhir iaitu gaya pembelajaran audio (1.955). Berdasarkan Jadual 12, perbezaan min adalah kecil dan dapat dirumuskan bahawa pelajar tahun pertama memiliki dua jenis gaya pembelajaran dan tidak terikat dengan hanya satu gaya sahaja. Dengan kata lain, pelajar dapat belajar dengan lebih baik jika diajar dengan menggunakan lebih dari satu deria. Walau bagaimanapun, gaya pembelajaran yang paling diberi keutamaan diamalkan dalam kalangan mahasiswa tahun pertama di Universiti Putra Malaysia adalah gaya pembelajaran visual dan kinestetik. Dapat dikonklusikan majoriti pelajar tahun pertama Universiti Putra Malaysia mempunyai tahap motivasi akademik yang tinggi untuk gaya pembelajaran visual dan kinestetik dengan skor min 2.203 dan 2.198. Tahap gaya pembelajaran bagi gaya pembelajaran audio berada di tahap yang rendah dengan skor min 1.938 .

Jadual 11: Skor Min Skala Likert untuk mengukur Gaya Pembelajaran

\begin{tabular}{ll}
\hline Skala Likert & Tahap Gaya Pembelajaran \\
\hline Skor Min 1.00-1.99 & Rendah \\
Skor Min 2.00 & Sederhana \\
Skor Min 2.01-3.00 & Tinggi \\
\hline
\end{tabular}

Jadual 12: Analisis Gaya Pembelajaran Responden ( $\mathrm{N}=351)$

\begin{tabular}{lll}
\hline Gaya Pembelajaran & Min & Sisih Piawaian \\
\hline Visual & 2.203 & 0.236 \\
Audio & 1.939 & 0.279 \\
Kinestetik & 2.198 & 0.236 \\
\hline
\end{tabular}

\section{Motivasi Akademik Intrinsik}

Tahap motivasi akademik intrinsik dalam kalangan mahasiswa tahun pertama di Universiti Putra Malaysia (min=2.698) berada pada tahap yang tinggi $(84.04 \%)$ dengan jumlah 309 pelajar. Seterusnya, tahap sederhana bagi golongan mahasiswa tahun pertama terhadap motivasi akademik intrinsik berada pada nilai $40(11.39 \%)$ dan berada pada tahap yang rendah $(0.57 \%)$ dengan jumlah 2 pelajar. Dapat dikonklusikan majoriti pelajar tahun pertama Universiti Putra Malaysia mempunyai tahap motivasi akademik intrinsik yang tinggi dengan skor sum 28-36.

Jadual 13: Motivasi Akademik Intrinsik dalam kalangan Responden $(\mathrm{N}=351)$

\begin{tabular}{lllll}
\hline $\begin{array}{l}\text { Tahap Motivasi Akademik } \\
\text { Intrinsik }\end{array}$ & Skala & Kekerapan & $\begin{array}{l}\text { Peratusan } \\
(\boldsymbol{\%})\end{array}$ & Min \\
\hline Rendah & $12-19$ & 2 & 0.57 & \\
Sederhana & $20-27$ & 40 & 11.39 & 2.698 \\
Tinggi & $28-36$ & 309 & 88.04 & \\
\hline
\end{tabular}

\section{Motivasi Akademik Ekstrinsik}

Tahap motivasi akademik ekstrinsik dalam kalangan mahasiswa tahun pertama di Universiti Putra Malaysia ( $\min =2.760)$ berada pada tahap yang tinggi $(91.74 \%)$ dengan jumlah 322 pelajar. Seterusnya, tahap sederhana bagi golongan mahasiswa tahun pertama terhadap motivasi akademik ekstrinsik berada pada nilai $28(7.98 \%)$ dan berada pada tahap yang rendah $(0.28 \%)$ dengan jumlah 1 pelajar. Dapat dikonklusikan majoriti pelajar tahun pertama Universiti Putra Malaysia mempunyai tahap motivasi akademik ekstrinsik yang tinggi dengan skor sum 28-36. 
Jadual 14: Motivasi Akademik Ekstrinsik dalam kalangan Responden ( $\mathrm{N}=351)$

\begin{tabular}{lllll}
\hline $\begin{array}{l}\text { Tahap Motivasi Akademik } \\
\text { Ekstrinsik }\end{array}$ & Skala & Kekerapan & $\begin{array}{l}\text { Peratusan } \\
(\boldsymbol{\%})\end{array}$ & Min \\
\hline Rendah & $12-19$ & 1 & 0.28 & \\
Sederhana & $20-27$ & 28 & 7.98 & 2.760 \\
Tinggi & $28-36$ & 322 & 91.74 & \\
\hline
\end{tabular}

\section{Motivasi Akademik Amotivasi}

Tahap motivasi akademik amotivasi dalam kalangan mahasiswa tahun pertama di Universiti Putra Malaysia (min=1.364) berada pada tahap yang rendah $(76.35 \%)$ dengan jumlah 268 pelajar. Seterusnya, tahap sederhana bagi golongan mahasiswa tahun pertama terhadap motivasi akademik amotivasi berada pada nilai $62(17.66 \%)$ dan berada pada tahap yang rendah $(5.98 \%)$ dengan jumlah 21 pelajar. Dapat dikonklusikan majoriti pelajar tahun pertama Universiti Putra Malaysia mempunyai tahap motivasi akademik amotivasi yang rendah dengan skor sum 4-6.

Jadual 15: Motivasi Akademik Amotivasi dalam kalangan Responden $(\mathrm{N}=351)$

\begin{tabular}{lllll}
\hline $\begin{array}{l}\text { Tahap Motivasi Akademik } \\
\text { Amotivasi }\end{array}$ & Skala & Kekerapan & $\begin{array}{l}\text { Peratusan } \\
(\boldsymbol{\%})\end{array}$ & Min \\
\hline Rendah & $4-6$ & 268 & 76.35 & \\
Sederhana & $7-9$ & 62 & 17.66 & 1.364 \\
Tinggi & $10-12$ & 21 & 5.98 & \\
\hline
\end{tabular}

\section{Analisis terhadap perhubungan antara Konsep Kendiri dengan Motivasi Akademik}

\section{Analisis korelasi pearson}

Analisis korelasi Pearson telah dijalankan bagi mengenal pasti hubungan antara konsep kendiri dan motivasi akademik dalam kalangan mahasiswa tahun pertama di Universiti Putra Malaysia.

Jadual 16: Kekuatan Hubungan Korelasi

\begin{tabular}{ll}
\hline Nilai Kolerasi $(\mathbf{r})$ & Kekuatan Kolerasi \\
\hline $\pm 0.91-1.0$ & Kolerasi sangat kuat \\
$\pm 0.71-0.90$ & Kolerasi kuat \\
$\pm 0.51-0.70$ & Kolerasi sederhana \\
$\pm 0.31-0.50$ & Kolerasi lemah \\
$\pm 0.01-0.30$ & Kolerasi sangat lemah \\
0.00 & Tiada kolerasi \\
\hline
\end{tabular}

Hipotesis kajian ini adalah seperti berikut, Ho1: Tiada perhubungan antara konsep kendiri dengan motivasi belajar dalam kalangan mahasiswa tahun pertama. Berdasarkan Jadual 17, ada perhubungan yang signifikan $\left(r=0.138^{* *}, \mathrm{p}=0.010\right)$ antara konsep kendiri dan motivasi akademik dalam kalangan mahasiswa tahun pertama di Universiti Putra Malaysia. Hal ini kerana, nilai signifikan $\mathrm{p}$ bagi perhubungan ini adalah lebih kecil daripada nilai alpha 0.01 iaitu sebanyak 0.01 . Tambahan lagi, nilai korelasi Pearson $r$ adalah 0.138, iaitu ditafsirkan sebagai kekuatan korelasi yang sangat lemah dengan merujuk pada Jadual 16. Jadi, hipotesis berjaya untuk ditolak dengan jayanya. 
Jadual 17: Analisis korelasi Pearson antara Konsep Kendiri dengan Motivasi Akademik

\begin{tabular}{lll}
\hline Pemboleh ubah & $\begin{array}{l}\text { Motivasi Akademik } \\
\mathbf{r}\end{array}$ & $\mathbf{p}$ \\
\hline Konsep Kendiri & 0.138 & 0.010 \\
\hline Korelasi signifikan pada tahap 0.01 &
\end{tabular}

\section{Analisis korelasi pearson antara Gaya Pembelajaran Visual dengan Motivasi Akademi}

Analisis korelasi Pearson telah dijalankan bagi mengenal pasti hubungan antara gaya pembelajaran visual dan motivasi akademik dalam kalangan mahasiswa tahun pertama di Universiti Putra Malaysia. Hipotesis kajian ini adalah seperti berikut, Ho2: Tiada perhubungan antara gaya pembelajaran visual dan motivasi dalam kalangan mahasiswa tahun pertama. Berdasarkan Jadual 18, ada perhubungan yang signifikan $(r=0.198 * *, p=0.000)$ antara gaya pembelajaran visual dan motivasi akademik dalam kalangan mahasiswa tahun pertama di Universiti Putra Malaysia. Hal ini kerana, nilai signifikan p bagi perhubungan ini adalah lebih kecil daripada nilai alpha 0.01 iaitu sebanyak 0.00 . Tambahan lagi, nilai korelasi Pearson $\mathrm{r}$ adalah 0.198, iaitu ditafsirkan sebagai kekuatan korelasi yang sangat lemah dengan merujuk pada Jadual 16. Jadi, hipotesis berjaya untuk ditolak dengan jayanya.

Jadual 18: Analisis korelasi Pearson antara Gaya Pembelajaran Visual dengan Motivasi Akademik

\begin{tabular}{lll}
\hline Pemboleh ubah & $\begin{array}{l}\text { Motivasi Akademik } \\
\mathbf{r}\end{array}$ & $\mathbf{p}$ \\
\hline Gaya Pembelajaran Visual & 0.198 & 0.000 \\
\hline Korelasi signifikan pada tahap 0.01
\end{tabular}

\section{Analisis korelasi pearson antara Gaya Pembelajaran Auditori dengan Motivasi Akademik}

Analisis korelasi Pearson telah dijalankan bagi mengenal pasti hubungan antara gaya pembelajaran auditori dan motivasi akademik dalam kalangan mahasiswa tahun pertama di Universiti Putra Malaysia. Hipotesis kajian ini adalah seperti berikut, Ho3: Tiada perhubungan antara gaya pembelajaran auditori dan motivasi dalam kalangan mahasiswa tahun pertama. Berdasarkan Jadual 19, tiada perhubungan yang signifikan $\left(r=0.106^{* *}, \mathrm{p}=0.047\right)$ antara gaya pembelajaran auditori dan motivasi akademik dalam kalangan mahasiswa tahun pertama di Universiti Putra Malaysia. Hal ini kerana, nilai signifikan $\mathrm{p}$ bagi perhubungan ini adalah lebih besar daripada nilai alpha 0.01 iaitu sebanyak 0.047. Tambahan lagi, nilai korelasi Pearson $r$ adalah 0.106, iaitu ditafsirkan sebagai kekuatan korelasi yang sangat lemah dengan merujuk pada Jadual 16. Jadi, hipotesis berjaya untuk ditolak dengan jayanya.

Jadual 19: Analisis korelasi Pearson antara Gaya Pembelajaran Auditori dengan Motivasi Akademik

\begin{tabular}{lll}
\hline Pemboleh ubah & $\begin{array}{l}\text { Motivasi Akademik } \\
\mathbf{r}\end{array}$ & $\mathbf{p}$ \\
\hline Gaya Pembelajaran Auditori & 0.106 & 0.047 \\
\hline Korelasi signifikan pada tahap 0.01 &
\end{tabular}




\section{Analisis korelasi pearson antara Gaya Pembelajaran Kinestetik dengan Motivasi Akademik}

Analisis korelasi Pearson telah dijalankan bagi mengenal pasti hubungan antara gaya pembelajaran kinestetik dan motivasi akademik dalam kalangan mahasiswa tahun pertama di Universiti Putra Malaysia. Hipotesis kajian ini adalah seperti berikut, Ho4: Tiada perhubungan antara gaya pembelajaran kinestetik dan motivasi dalam kalangan mahasiswa tahun pertama. Berdasarkan Jadual 20 , ada perhubungan yang signifikan $\left(r=0.145^{* *}, p=0.006\right)$ antara gaya pembelajaran kinestetik dan motivasi akademik dalam kalangan mahasiswa tahun pertama di Universiti Putra Malaysia. Hal ini kerana, nilai signifikan $\mathrm{p}$ bagi perhubungan ini adalah lebih kecil daripada nilai alpha 0.01 iaitu sebanyak 0.006. Tambahan lagi, nilai korelasi Pearson $r$ adalah 0.145 , iaitu ditafsirkan sebagai kekuatan korelasi yang sangat lemah dengan merujuk pada Jadua 16. Jadi, hipotesis berjaya untuk ditolak dengan jayanya.

Jadual 20: Analisis korelasi Pearson antara Gaya Pembelajaran Kinestetik dengan Motivasi Akademik

\begin{tabular}{lll}
\hline Pemboleh ubah & $\begin{array}{l}\text { Motivasi Akademik } \\
\mathbf{r}\end{array}$ & $\mathbf{p}$ \\
\hline Gaya Pembelajaran Kinestetik & 0.145 & 0.006 \\
\hline
\end{tabular}

Korelasi signifikan pada tahap 0.01

\section{Analisis terhadap perbezaan Konsep Kendiri, Gaya Pembelajaran dan Motivasi Akademik antara Jantina}

\section{Konsep Kendiri dan Jantina}

Analisis ujian-T telah dilakukan untuk mengenal pasti perbezaan jantina dan konsep kendiri dalam kalangan mahasiswa tahun pertama di Universiti Putra Malaysia. Hipotesis kajian ini adalah seperti berikut; Ho 5: Tiada perbezaan yang signifikan dalam konsep kendiri antara jantina lelaki dan perempuan dalam kalangan mahasiswa tahun pertama. Berdasarkan Jadual 21, wujud perbezaan yang signifikan $(\mathrm{t}=-3.201, \mathrm{p}=0.01)$ antara konsep kendiri mahasiswa tahun pertama di Universiti Putra Malaysia berdasarkan jantina sama ada lelaki mahupun perempuan. Jadi, hipotesis berjaya untuk ditolak dengan jayanya.

Jadual 21: Analisis Ujian-T antara perbezaan Jantina dan Konsep Kendiri (N=351)

\begin{tabular}{lllll}
\hline \multirow{2}{*}{ Pemboleh ubah } & \multicolumn{2}{l}{ Min } & \multirow{2}{*}{$\mathbf{~}$} & \multirow{2}{*}{} \\
\cline { 2 - 5 } & Lelaki & Perempuan & & 0.01 \\
\hline Konsep Kendiri & 2.3256 & 2.3842 & -3.201 & 0. \\
\hline
\end{tabular}

\section{Gaya Pembelajaran dan Jantina}

Analisis ujian-T telah dilakukan untuk mengenal pasti perbezaan jantina dan gaya pembelajaran visual dalam kalangan mahasiswa tahun pertama di Universiti Putra Malaysia. Hipotesis kajian ini adalah seperti berikut; Ho 6: Tiada perbezaan yang signifikan dalam gaya pembelajaran visual antara jantina lelaki dan perempuan dalam kalangan mahasiswa tahun pertama. Berdasarkan Jadual 22, wujud perbezaan yang signifikan $(\mathrm{t}=-3.032, \mathrm{p}=0.03)$ antara gaya pembelajaran visual mahasiswa tahun pertama di Universiti Putra Malaysia berdasarkan jantina sama ada lelaki mahupun perempuan. Pelajar perempuan $(\min =2.2280)$ dilihat memiliki tahap gaya pembelajaran visual yang lebih tinggi daripada pelajar lelaki ( $\min =2.1463)$. Jadi, hipotesis berjaya untuk ditolak dengan jayanya. 
Jadual 22: Analisis Ujian-T antara perbezaan Jantina dan Gaya Pembelajaran Visual (N=351)

\begin{tabular}{lllll} 
Pemboleh ubah & \multicolumn{1}{l}{ Min } & \multicolumn{1}{l}{} & $\mathbf{p}$ \\
\cline { 2 - 3 } Gaya Pembelajaran Visual & Lelaki & Perempuan & & 0.03 \\
\cline { 2 - 3 } & 2.1463 & 2.2280 & -3.032 & 0.03 \\
\hline
\end{tabular}

Analisis ujian-T telah dilakukan untuk mengenal pasti perbezaan jantina dan gaya pembelajaran auditori dalam kalangan mahasiswa tahun pertama di Universiti Putra Malaysia. Hipotesis kajian ini adalah seperti berikut; Ho 7: Tiada perbezaan yang signifikan dalam gaya pembelajaran auditori antara jantina lelaki dan perempuan dalam kalangan mahasiswa tahun pertama. Berdasarkan Jadual 23, tidak wujud perbezaan yang signifikan $(\mathrm{t}=0.445, \mathrm{p}=0.657)$ antara gaya pembelajaran auditori mahasiswa tahun pertama di Universiti Putra Malaysia berdasarkan jantina sama ada lelaki mahupun perempuan. Jadi, hipotesis gagal untuk ditolak.

Jadual 23: Analisis Ujian-T antara perbezaan Jantina dan Gaya Pembelajaran Auditori ( $\mathrm{N}=351)$

\begin{tabular}{lllll}
\hline \multirow{2}{*}{ Pembolehubah } & \multicolumn{2}{l}{ Min } & \multirow{2}{*}{$\mathbf{~}$} & \multirow{2}{*}{} \\
\cline { 2 - 4 } & Lelaki & Perempuan & \\
\hline Gaya Pembelajaran Auditori & 1.9491 & 1.9346 & 0.445 & 0.657 \\
\hline
\end{tabular}

Analisis ujian-T telah dilakukan untuk mengenal pasti perbezaan jantina dan gaya pembelajaran kinestetik dalam kalangan mahasiswa tahun pertama di Universiti Putra Malaysia. Hipotesis kajian ini adalah seperti berikut; Ho 8: Tiada perbezaan yang signifikan dalam gaya pembelajaran kinestetik antara jantina lelaki dan perempuan dalam kalangan mahasiswa tahun pertama. Berdasarkan Jadual 24, tidak wujud perbezaan yang signifikan $(t=0.608, p=0.544)$ antara gaya pembelajaran kinestetik mahasiswa tahun pertama di Universiti Putra Malaysia berdasarkan jantina sama ada lelaki mahupun perempuan. Jadi, hipotesis gagal untuk ditolak.

Jadual 24: Analisis Ujian-T antara perbezaan Jantina dan Gaya Pembelajaran Kinestetik ( $\mathrm{N}=351)$

\begin{tabular}{lllll}
\hline \multirow{2}{*}{ Pemboleh ubah } & Min & \multicolumn{2}{l}{} & \multirow{2}{*}{$\mathbf{p}$} \\
\cline { 2 - 5 } & Lelaki & Perempuan & & 0.608 \\
\hline Gaya Pembelajaran Kinestetik & 2.2111 & 2.1922 & 0.544 \\
\hline
\end{tabular}

\section{Motivasi Akademik dan Jantina}

Analisis ujian-T telah dilakukan untuk mengenal pasti perbezaan jantina dan motivasi akademik intrinsik dalam kalangan mahasiswa tahun pertama di Universiti Putra Malaysia. Hipotesis kajian ini adalah seperti berikut; Ho 9: Tiada perbezaan yang signifikan dalam motivasi akademik intrinsik antara jantina lelaki dan perempuan dalam kalangan mahasiswa tahun pertama. Berdasarkan Jadual 25, terdapat perbezaan yang signifikan $(\mathrm{t}=3.601, \mathrm{p}=0.000)$ antara motivasi akademik intrinsik mahasiswa tahun pertama di Universiti Putra Malaysia berdasarkan jantina sama ada lelaki mahupun perempuan. Pelajar perempuan $(\min =2.7390)$ dilihat memiliki tahap motivasi akademik intrinsik yang lebih tinggi daripada pelajar lelaki $(\mathrm{min}=2.6080)$. Jadi, hipotesis berjaya untuk ditolak dengan jayanya.

Jadual 25: Analisis Ujian-T antara perbezaan Jantina dan Motivasi Akademik Intrinsik ( $\mathrm{N}=351)$

\begin{tabular}{|c|c|c|c|c|}
\hline \multirow{2}{*}{ Pemboleh ubah } & \multicolumn{2}{|l|}{ Min } & & \multirow[b]{2}{*}{$\mathrm{p}$} \\
\hline & Lelaki & Perempuan & $\mathrm{t}$ & \\
\hline Motivasi Akademik Intrinsik & 2.6080 & 2.7390 & -3.601 & 0.000 \\
\hline
\end{tabular}

Analisis ujian-T telah dilakukan untuk mengenal pasti perbezaan jantina dan motivasi akademik ekstrinsik dalam kalangan mahasiswa tahun pertama di Universiti Putra Malaysia. Hipotesis kajian ini adalah seperti berikut; Ho 10: Tiada perbezaan yang signifikan dalam motivasi akademik ekstrinsik antara jantina lelaki dan perempuan dalam kalangan mahasiswa tahun pertama. Berdasarkan Jadual 26, terdapat perbezaan yang signifikan $(\mathrm{t}=-2.951, \mathrm{p}=0.03)$ antara motivasi akademik ekstrinsik 
mahasiswa tahun pertama di Universiti Putra Malaysia berdasarkan jantina sama ada lelaki mahupun perempuan. Pelajar perempuan $(\mathrm{min}=2.7891)$ dilihat memiliki tahap motivasi akademik ekstrinsik yang lebih tinggi daripada pelajar lelaki $(\min =2.6944)$. Jadi, hipotesis berjaya untuk ditolak dengan jayanya.

Jadual 26: Analisis Ujian-T antara perbezaan Jantina dan Motivasi Akademik Ekstrinsik ( $\mathrm{N}=351)$

\begin{tabular}{|c|c|c|c|c|}
\hline \multirow{2}{*}{ Pemboleh ubah } & \multicolumn{2}{|l|}{ Min } & \multirow[b]{2}{*}{$\mathbf{t}$} & \multirow[b]{2}{*}{$\mathbf{p}$} \\
\hline & Lelaki & Perempuan & & \\
\hline Motivasi Akademik Ekstrinsik & 2.6944 & 2.7891 & -2.951 & 0.030 \\
\hline
\end{tabular}

Analisis ujian-T telah dilakukan untuk mengenal pasti perbezaan jantina dan motivasi akademik amotivasi dalam kalangan mahasiswa tahun pertama di Universiti Putra Malaysia. Hipotesis kajian ini adalah seperti berikut; Ho 11: Tiada perbezaan yang signifikan dalam motivasi akademik amotivasi antara jantina lelaki dan perempuan dalam kalangan mahasiswa tahun pertama. Berdasarkan Jadual 27, terdapat perbezaan yang signifikan $(\mathrm{t}=4.550, \mathrm{p}=0.000)$ antara motivasi akademik amotivasi mahasiswa tahun pertama di Universiti Putra Malaysia berdasarkan jantina sama ada lelaki mahupun perempuan. Pelajar lelaki $(\mathrm{min}=1.5370)$ dilihat memiliki tahap motivasi akademik amotivasi yang lebih tinggi daripada pelajar perempuan $(\min =1.2870)$. Jadi, hipotesis berjaya untuk ditolak dengan jayanya.

Jadual 27: Analisis Ujian-T antara perbezaan Jantina dan Motivasi Akademik Amotivasi ( $\mathrm{N}=351)$

\begin{tabular}{lllll}
\hline Pemboleh ubah & Min & Perempuan & $\mathbf{t}$ & $\mathbf{p}$ \\
\hline Motivasi Akademik Amotivasi & 1.5370 & 1.2870 & 4.550 & 0.000 \\
\hline
\end{tabular}

\section{Perbincangan}

\section{Latar Belakang Respondenyang Terlibatdalam Kajian}

Hasil daripada analisis kajian mendapati bahawa majoriti responden adalah berumur 19 hingga 20 tahun. Berdasarkan data tersebut dapat dirumuskan bahawa pelajar tahun pertama sesi 2019/2020 adalah lepasan program matrikulasi dan sijil tinggi pelajaran Malaysia. Seterusnya, seramai 3 responden yang berumur 18 tahun adalah pelajar lepasan fast track. Manakala, pelajar berumur 21 dan 22 tahun adalah lepasan diploma. Dari segi bangsa, majoriti responden adalah berbangsa Melayu dan diikuti dengan bangsa Cina, India, Iban, Bidayuh dan orang asli. Jelas terbukti kerana komposisi bangsa di Malaysia juga Melayu merupakan majoriti dengan 68.88\% diikuti dengan bangsa cina 25.56 $\%, 6.73 \%$ bangsa India dan lain-lain bangsa seramai $0.9 \%$. Peluang memasuki ke universiti awam juga diberikan kepada lebih ramai kaum bumiputera berbanding kaum lain ni negara ini. Dari segi agama pula, agama Islam merupakan golongan majoriti dalam kalangan responden dan golongan minoriti merupakan agama Kristian. Ini kerana pemilihan responden dilakukan secara rawak menyebabkan kajian yang dilakukan tidak menumpukan pada agama. Akhir sekali, dari segi pendapatan keluarga pula majoriti responden adalah dalam kumpulan B40 iaitu pendapatan isi rumah bulanan adalah di bawah RM3860.00. Diikuti dengan kumpulan M40 iaitu pendapatan isi rumah bulanan antara RM3860.00 hingga RM8319.00. Kumpulan minoriti dalam kalangan responden adalah kumpulan T20 iaitu isi rumah yang berpendapatan bulanan RM8319.00 dan ke atas. Jelas dapat dilihat bahawa ramai pelajar dalam kumpulan B40 sebenarnya mempunyai kemampuan akal yang hebat yang mampu membawa mereka sampai memasuki universiti. Akses pelajar-pelajar terhadap pendidikan tinggi merupakan langkah untuk keluar dari kelompok kemiskinan. 


\section{Tahap Konsep Kendiri dalam Kalangan Responden}

Hasil analisis data yang dikumpulkan daripada 351 responden mendapati, tahap konsep kendiri mahasiswa tahun pertama berada di tahap yang tinggi. Ini menunjukkan bahawa pelajar tahun pertama sangat positif dan mempercayai terhadap diri sendiri. Mereka mempunyai semangat yang baru dalam menempuh alam yang baru. Pelajar dengan jumlah min tertinggi menyatakan bahawa mereka berbangga dengan keluarga. Ini berkemungkinan kerana ahli keluarga mereka juga merupakan graduan universiti atau merupakan tulang sokongan terhadap kejayaan mereka selama ini. Sebagai contoh, ibu bapa selalunya merupakan sumber inspirasi kepada anak-anak. Segala usaha yang dilakukan oleh ibu bapa dalam mencari rezeki secara tidak langsung mengajar pelajar untuk berusaha keras untuk mencapai kejayaan. Sangatlah besar pengorbanan ibu bapa untuk melihat kita menjadi seorang yang berguna dan berjaya. Hal ini disokong oleh kajian yang dilakukan oleh Tawi (2019) yang menyatakan bahawa jika dalam ahli keluarga terdapat abang atau kakak yang berjaya dalam pelajaran di peringkat Doktor Falsafah, hal ini akan mempengaruhi pelajar untuk terus yakin dengan diri sendiri untuk belajar.

Pelajar UPM juga menyatakan bahawa kehidupan mereka dipengaruhi oleh orang-orang yang penting seperti keluarga, rakan-rakan dan guru. Sokongan dari rakan-rakan dapat meningkatkan kepercayaan diri dan semangat seseorang itu. Keluarga pula merupakan orang yang paling dekat dengan individu. Dengan kasih sayang dan layanan yang baik dapat membentuk konsep kendiri yang positif. Dengan sokongan yang berterusan dari orang-orang yang penting, pelajar tidak akan rasa kekosongan atau kekurangan dalam hidup malah akan rasa dihargai dan ada orang bersama mereka dalam melakukan sesuatu. Menurut Hattie (1992), ibu bapa dan rakan sebaya adalah penentu yang signifikan dan dapat mempengaruhi konsep kendiri dan kepercayaan diri seseorang. Dapatan kajian ini selari dengan dapatan kajian Faizan et al. (2016) di mana pelajar mempunyai konsep kendiri yang sangat baik dan dapat membantu dalam proses pembelajaran dan pengajaran semasa di universiti.

Selain itu, rasa diri sendiri pandai dan bijak juga merupakan antara faktor peningkatan konsep kendiri dalam seseorang individu. Misalnya, jika pada suatu masa seorang pelajar itu merasakan bahawa mereka lemah, rendah diri dan tidak yakin, mereka harus mengimbau kembali kejayaan di masa lalu. Pelajar tahun pertama sudah semestinya merasakan mereka bijak dan pandai kerana mereka mampu memperoleh kedudukan di Universiti lebih-lebih universiti awam. Pelajar yang sentiasa merasakan diri mereka kurang bijak dan bukan siapa-siapa haruslah mengambil langkah awal dengan mendekatkan diri dengan orang yang mampu memberi kata-kata membangun seperti ibu bapa, rakan-rakan, guru atau kaunselor. Kaunselor merupakan orang yang paling tepat yang boleh membimbing dan menolong seseorang pelajar itu untuk faham diri mereka sendiri. Pelajar dapat memahami sikap, minat, bakat dan kebolehan yang ada dalam diri mereka. Terdapat kajian lepas yang dilakukan oleh Saputra dan Prasetiawan (2018), yang menyatakan bahawa kepercayaan diri siswa dapat ditingkatkan melalui Teknik Cognitive Defusion. Memang benar, teknik menggunakan kaunseling ini dapat dilakukan untuk mengurangi fikiran negatif pelajar terhadap diri mereka sendiri.

Tambahan pula, pelajar tahun pertama Universiti Putra Malaysia juga dikatakan gemar berpakaian kemas. Pakaian yang kemas akan membuat pelajar berpendapat baik tentang mereka sendiri dan pakaian yang sesuai juga dapat meningkatkan prestasi. Walaupun jika pelajar itu mempunyai badan yang gempal atau kulit yang gelap, tetapi jika pelajar pandai untuk mengenakan solekan dan boleh sesuaikan diri dengan busana pasti dapat menyerlahkan penampilan mereka. Setiap pelajar yang yakin dengan diri mereka sendiri dan kecantikan dari dalaman itu akan muncul dengan sendirinya. Kajian oleh Musa dan Roach ( 1973) yang menyatakan bahawa penampilan peribadi mempengaruhi konsep kendiri, Jelaslah, bahawa cara pakaian pelajar memang memberi pengaruh kepada dalaman individu dan apa yang difikirkan orang terhadap kita. Pada pandangan saya juga, setiap cara pemakaian kita sebenarnya berkait rapat dengan kecerdasan kita di sesuatu tempat. Misalnya, pelajar hanya perlu pakai kemeja, baju kurung, kasut bertutup dan mengambil berat terhadap pakaian sebelum kita memakai dan hal ini boleh membuatkan diri rasa bijak dan matang.

Pelajar tahun pertama Universiti Putra Malaysia juga dikatakan mudah untuk berkawan dan sesuaikan diri dengan orang lain. Mereka yang baru memasuki alam yang baru, iaitu kehidupan yang berjauhan 
dengan keluarga dan hidup berasrama sudah semestinya ingin mencari rakan baru supaya dapat sokongan sosial. Contohnya, pelajar pandai bergaul dengan semua jenis pelajar sama ada pemalu, periang, bijak, pelajar tidak cemerlang, pendiam, peramah dan pembuli. Rata-rata pelajar UPM juga dikatakan mempunyai kawan rapat di tempat belajar. Kawan rapat adalah faktor penting dalam mencapai kejayaan. Kawan-kawan dapat memberi semangat untuk berjaya kelak, kawan-kawan dapat membantu kita di saat susah dan senang dan kawan-kawan juga dapat membimbing ke arah kebaikan.

\section{Tahap Gaya Pembelajaran dalam Kalangan Responden}

Melalui penyelidikan ini, didapati responden lebih memilih dua gaya pembelajaran iaitu visual dan kinestetik. Pemilihan pembelajaran lebih dari satu tidak menghairankan. Pelajar menggunakan lebih dari satu deria mereka untuk menerima maklumat pada satu tempoh masa tertentu. Hal ini menyokong kajian yang pernah dijalankan oleh Wehrwein et al. (2007) yang mana mereka mendapati bahawa pelajar akan lebih memilih arahan multi modal. Menurut mereka, salah satu cara untuk tingkatkan prestasi adalah dengan menyesuaikan pendekatan gaya pengajaran untuk memenuhi pemilihan gaya pembelajaran pelajar yang berbeza.

Bagi gaya pembelajaran visual, pelajar tahun pertama dikatakan lebih menulis nota untuk mengingati sesuatu. Sebagai contoh, jika pelajar belajar sesuatu yang baru dengan nama-nama saintifik yang baru didengar, mereka akan ingat nama tersebut untuk beberapa saat dan apabila tumpuan sepenuhnya tidak diberikan sepenuhnya kepadanya, maka apa yang dipelajarinya akan hilang. Pelajar tahun pertama, lebih memilih untuk mencatat nota apa yang mereka pelajari supaya dapat membuat ulang kaji dan sebagai rujukan sewaktu peperiksaan kelak. Kadang-kadang, informasi dan contoh yang disampaikan pensyarah sewaktu kuliah adalah lebih untuk difahami oleh pelajar. Jika pelajar membuat nota, maka pelajar boleh "recall" kembali apa yang dipelajari mereka. Mungkin juga, pelajar-pelajar gaya pembelajaran visual ini membuat nota untuk memudahkan proses mengingat dan untuk mendapatkan kefahaman yang menyeluruh tanpa perlu penerangan lisan Sebagai contoh, apabila pensyarah sedang mengajar, dan apabila kita tulis apa yang dipelajari fikiran akan kekal fokus dengan apa yang kita tuliskan. Pelajar visual akan elakkan diri mereka dari tidak leka ketika belajar.

Seterusnya, pelajar ini juga dikatakan lebih memilih untuk melakukan kerja di tempat yang sunyi dan tenang. Pelajar-pelajar tahun pertama ini lebih suka untuk belajar di tempat yang sunyi kerana dapat memberi konsentrasi terhadap apa yang mereka pelajari. Selalunya, mereka yang suka belajar di tempat yang sunyi ini suka belajar bersendirian berbanding belajar secara berkumpulan. Mungkin juga jika belajar beramai-ramai dengan suara yang bising akan menyebabkan pelajar tidak dapat fokus dan tumpukan perhatian. Berbalik kepada kajian yang dilakukan oleh Samah (1995), di mana beliau menyatakan bahawa persekitaran yang berbunyi dapat kurangkan minat pelajar untuk belajar. Mereka juga tidak boleh terganggu oleh pergerakan yang boleh mengalihkan perhatian. Menyokong dengan pernyataan itu. Pelajar UPM lebih cenderung untuk melakukan kerja di tempat sunyi seperti perpustakaan. Selalunya dapat dilihat pada waktu puncak ramai sangat pelajar yang akan datang ke perpustakaan untuk melakukan kerja atau belajar.

Selain itu, pelajar tahun pertama juga dikatakan untuk suka doodling dan mempunyai banyak gambar dalam nota mereka. Seseorang pelajar yang belajar untuk doodle dapat membantu diri mereka untuk memahami pembahagian dan dimensi sesuatu tugasan itu sekali gus mengurangkan kerisauan dan tekanan. Pelajar visual adalah pelajar yang lebih suka untuk belajar dengan melihat gambar, demonstrasi atau simbol. Sebagai contoh, terdapat dua jenis pelajar. Jika seseorang menyebut perkataan awan, pelajar A akan terus terbayang awan di langit, manakala pelajar B akan terbayang tulisan a.w.a.n. Pelajar A adalah pelajar yang lebih cenderung terhadap pembelajaran visual. Dengan menukarkan apa yang dipelajari kepada gambar, adalah lebih mudah untuk mengingatkannya berbanding dengan hanya mendengarnya sahaja.

Tambahan pula, pelajar ini juga dikatakan dapat melihat halaman buku teks dan lokasi jawapan apabila mengambil ujian. Pelajar memiliki imaginasi yang terang kerana dapat berfikir dalam gambaran dan gambarkan sesuatu secara lebih terperinci. Ini bermaksud, apabila pelajar melihat buku, mereka boleh menghafal secara visual sekali dengan halaman buku yang dipelajari. Sebagai contoh, 
apabila soalan peperiksaan yang lebih kurang dengan apa yang dipelajarinya, maka pelajar tersebut akan teringat kembali nota-nota dalam buku yang dipelajarinya.

Bagi gaya pembelajaran auditori, pelajar tahun pertama dikatakan untuk lebih ingat perkara yang mereka dengar daripada perkara yang mereka lihat atau baca. Misalnya, pelajar auditori lebih menggunakan pendengaran sebagai medium untuk mencapai keberkesanan dalam proses pembelajaran. Sebagai contoh, pelajar tahun pertama lebih memilih untuk adanya kuliah secara verbal dengan pensyarah dan dengar apa yang diajar oleh pensyarah mereka. Pernyataan di atas disokong oleh kajian yang dilakukan oleh Mustaffa (2007) yang menyatakan bahawa dalam sesi kelas, kefahaman pelajar auditori adalah lebih tinggi jika diberi pengajaran dalam bentuk lisan berbanding cetakan. Pelajar ini lebih suka untuk belajar dengan cara mengeluarkan suara ketika menghafal atau mengerakkan bibir mereka. Terdapat juga segelintir pelajar yang suka untuk merakam apa yang diajar pensyarah mereka dalam kelas. Hal ini kerana mereka gemar untuk membuat ulang kaji kembali secara mendengar rakaman.

Seterusnya, pelajar auditori juga dikatakan lebih faham bagaimana untuk melakukan sesuatu jika seseorang ajar berbanding harus memahaminya sendiri. Seperti yang sedia maklum, responden kajian ini adalah mahasiswa tahu pertama. Mereka masih baru dan mengharapkan tunjuk ajar yang mendalam daripada harus terokainya sendiri. Misalnya, jika harus melakukan tugasan makmal, pelajar auditori lebih memilih jika guru membuat demonstrasi terlebih dahulu dan mendapat penjelasan penuh daripada harus mempelajari cara melalui Youtube atau nota kuliah. Ini disokong oleh kajian yang dilakukan oleh Mustaffa (2007) yang mana pengkaji menyatakan bahawa pelajar akan berasa sukar untuk sesuaikan diri dengan proses pengajaran di mana harus membaca sendiri nota yang diberikan. Hal tersebut akan menyebabkan bosan dan mudah putus asa. Pada pandangan saya, saya bersetuju. Jika kita belajar sesuatu dengan sendiri tanpa mendapat kepastian daripada pensyarah, sedikit sebanyak akan rasa keliru kita tersalah erti maksud yang disampaikan nota. Walau bagaimanapun, pelajar sudah memasuki alam universiti, pelajar harus lebih berdikari dengan membuat penyelidikan tambahan tanpa mengharapkan pensyarah "menyuap" semua maklumat.

Bagi gaya pembelajaran kinestetik, pelajar tahun pertama dikatakan untuk berfikir dengan lebih baik apabila boleh bergerak dengan bebas. Hasil analisis juga mendapati sebahagian daripada pelajar memerlukan rehat yang kerap dan bergerak dengan bebas untuk lebih cemerlang dalam belajar. Misalnya, ingatan lebih jelas jika belajar disertakan dengan gerakan. Sebagai contoh, apabila belajar geografi, pelajar mungkin bosan dan susah untuk mengingat bentuk peta dan nama lokasi. Apabila keadaan seperti ini berlaku, pelajar boleh berdiri atau berjalan sambil cuba buat apa-apa akronim atau gerakan yang boleh melambangkan peta tersebut. Dengan itu, pelajar dapat hafal dengan lebih berkesan. Selain itu, mungkin juga, pelajar tahun pertama ini lebih suka dan bebas untuk bergerak semasa belajar. Sebagai contoh, pada mulanya pelajar belajar di atas meja, kemudian pelajar melakukan sikit pergerakan seperti berpindah ke ruang tamu pula untuk belajar.

Selain itu, pelajar ini juga dikatakan penggunaan jari sebagai penunjuk membantu semasa membaca sesuatu. Dengan menggunakan jari sebagai "pointer" ketika membaca akan memfokuskan pelajar dalam pembacaan mereka. Misalnya, apabila menggunakan jari, secara tidak langsung kita akan membaca sesuatu dengan lebih pantas kerana mata akan memberi fokus dengan apa yang ditunjukkan jari untuk membaca. Kemungkinan pelajar tahun pertama ini menggunakan jari mereka untuk menyatakan isi-isi penting apa yang mereka pelajari. Mungkin juga, pelajar guna jari kerana mereka sedikit lambat ketika membaca. Dengan adanya petunjuk jari mereka boleh mengikut pergerakan perkataan itu perlahan demi perlahan.

Tambahan lagi, pelajar tahun pertama juga dikatakan belajar sesuatu dengan lebih baik apabila ditunjukkan bagaimana untuk melakukan sesuatu, dan apabila ada peluang untuk melakukannya. Hal ini kerana, mereka belajar dengan lebih baik dengan libatkan diri secara fizikal dalam kelas dan juga akan mengingati sesuatu dengan baik apabila melakukan aktiviti secara "hands-on". Mungkin pelajar ini adalah pelajar kos engineering atau fizik yang memerlukan latihan secara amali atau praktikal lebih-lebih aktiviti yang memerlukan penglibatan alatan. Mereka lebih memilih untuk libatkan anggota fizikal Contohnya, pelajar kinestetik ini lebih suka melakukan uji kaji atau demonstrasi tentang apa 
yang mereka belajar. Akhir sekali, pelajar kinestetik cenderung untuk menyelesaikan masalah melalui pendekatan percubaan dan kesilapan daripada kaedah langkah demi langkah. Mereka akan mencuba perkara yang baru dengan merasakan dan memanipulasi informasi.

\section{Tahap Motivasi Akademik dalam Kalangan Responden}

Hasil analisis data yang dikumpulkan daripada 351 responden mendapati, motivasi akademik mahasiswa tahun pertama berada di tahap yang tinggi. Untuk motivasi intrinsik didapati, majoriti mahasiswa tahun pertama menyatakan bahawa mereka merasakan bahawa seronok untuk mempelajari perkara-perkara baru. Misalnya, pelajar tahun pertama baru melangkah masuk alam yang baru, iaitu alam yang dari sebelumnya. Mereka mempunyai impian mereka yang tersendiri dan ada kekuatan dari dalam untuk capai apa yang mereka inginkan. Selain itu, dapat dilihat bahawa pelajar tahun pertama pergi ke universiti untuk mendapat gaji yang lumayan kelak.

Dapat dilihat bahawa pelajar tahun pertama, sudah mula peka bahawa dengan adanya ijazah, sudah pasti gaji yang diterima juga akan bertambah. Mereka mempunyai tanggapan di mana, semakin tinggi kelulusan seseorang, maka semakin mudah untuk mendapat peluang pekerjaan. Hal ini sangat bertepatan dengan kajian yang dilakukan oleh Ismail dan Rajuddin (2012), di mana mereka menyatakan bahawa setiap pelajar akan mempunyai keinginan dan harapan dalam bidang yang mereka lakukan kerana ia akan menjadi pemangkin dalam pekerjaan yang mereka akan ceburi kelak. Menurut mereka, jurusan yang diceburi pelajar akan memberi kesan kepada perancangan dalam pemilihan kerjaya mereka kelak.

Bagi motivasi ekstrinsik, majoriti responden menyatakan bahawa mereka percaya bahawa pendidikan di universiti akan meningkatkan kecekapan mereka sebagai seorang pelajar. Pada pandangan mereka, dengan belajar mereka dapat mengasah bakat yang mereka sendiri belum terokai dan belajar banyak perkara yang baru. Sebagai contoh, mereka cekap dalam berfikir secara ilmiah dan membuat percubaan dengan pendekatan ilmiah. Hal ini selari dengan kajian yang dilakukan oleh Kar et. al. (2012) dimana dengan pergi ke sekolah dapat tingkatkan kecekapan pertanyaan pelajar dengan bimbingan guru di sekolah.

\section{Perhubungan Antara Konsep Kendiri dan Motivasi Akademik dalam Kalangan Responden}

Merujuk pada hipotesis kajian ini, tiada perhubungan yang signifikan antara konsep kendiri dengan motivasi akademik dalam kalangan mahasiswa tahun pertama di Universiti Putra Walau bagaimanapun, dapatan kajian menunjukkan bahawa terdapat perhubungan antara konsep kendiri dan motivasi akademik. Dapatan kajian ini sejajar dengan kajian yang dilakukan oleh Izuchi dan Onyekuru yang menyatakan terdapat perhubungan yang positif antara konsep kendiri dan motivasi akademik. Perhubungan yang positif antara konsep kendiri dan motivasi akademik mungkin disebabkan kerana apabila mempunyai motivasi akademik yang tinggi, sekali gus dapat membantu dalam menanam keyakinan diri yang tinggi dalam diri pelajar. Pelajar yang secara konsisten mendapat penilaian yang positif dapat membina keyakinan diri yang tinggi yang boleh menghasilkan pembentukan motivasi yang positif untuk tugas-tugas akademik pada masa akan datang.

Hasil dapatan kajian ini menjelaskan bahawa cara seseorang pelajar memandang diri mereka mempunyai impak yang sangat penting dalam aspek psikologi. Pandangan yang positif dengan diri, menerima dan menghargai kelebihan diri akan memberi rasa tenang dan secara automatik meningkatkan keinginan untuk berjaya dalam pembelajaran. Dalam meneruskan kehidupan alam pembelajaran, adalah sangat penting untuk memiliki konsep kendiri yang positif kerana hal ini bersangkut paut dengan motivasi, prestasi dalam pendidikan dan hubungan dengan orang sekeliling. Terdapat faktor-faktor yang sedikit sebanyak dapat mempengaruhi konsep kendiri iaitu minat, emosi, hubungan dengan keluarga dan rakan-rakan serta tahap mana penghargaan terhadap diri mereka. 


\section{Perhubungan antara Gaya Pembelajaran dan Motivasi Akademik dalam Kalangan Responden}

Merujuk pada hipotesis kajian ini, tiada perhubungan yang signifikan antara ketiga-tiga gaya pembelajaran dengan motivasi akademik dalam kalangan mahasiswa tahun pertama di Universiti Putra Malaysia. Walau bagaimanapun, dapatan kajian menunjukkan bahawa terdapat perhubungan yang signifikan antara gaya pembelajaran visual dan kinestetik dengan motivasi akademik tetapi pada kekuatan korelasi yang rendah. Dalam kajian yang dilakukan moleh Rashid (2007) yang menyatakan bahawa tidak terdapat perhubungan antara gaya pembelajaran visual dan auditori dengan motivasi. Hal ini berkemungkinan kerana kajian yang dilakukan di kawasan luar Bandar, sabah tetapi kajian yang dilakukan fokus di kawasan bandar.

Berlawanan dengan kajian yang dilakukan oleh Daud dan Mukhlisa (2016) di mana terdapat perhubungan gaya pembelajaran dengan motivasi pembelajaran. Ini bermaksud, dengan memahami gaya pembelajaran, pelajar dapat mengawal dalam proses pembelajaran, iaitu meningkat motivasi pembelajaran. Dapat dikatakan bahawa gaya pembelajaran adalah pendekatan yang menerangkan bagaimana cara seseorang individu belajar supaya sentiasa komited dan bersemangat dalam urusan akademik. Dengan adanya motivasi yang baik, akan mendorong pelajar untuk jadi lebih aktif dalam meningkatkan pencapaian akademik. Pelajar haruslah terus menerokai gaya belajar yang paling bersesuaian dengan diri mereka agar dapat mencapai proses pembelajaran yang efektif. Hal ini sekali gus dapat tingkatkan motivasi belajar pelajar.

\section{Perbezaan antara Konsep kendiri, Gaya Pembelajaran dan Motivasi Akademik antara Jantina dalam Kalangan Responden}

Keputusan kajian mendapati bahawa tahap motivasi akademik mahasiswa tahun pertama di Universiti Putra Malaysia adalah tinggi. Berdasarkan hipotesis pertama dalam kajian ini di mana tidak mempunyai perbezaan yang signifikan dalam konsep kendiri, gaya pembelajaran dan motivasi akademik antara perbezaan jantina lelaki dan perempuan dalam kalangan mahasiswa tahun pertama di Universiti Putra Malaysia.

Berdasarkan analisis, dapat dilihat bahawa pelajar lelaki mendapat skor min yang lebih tinggi dari perempuan dalam pernyataan mudah berkawan dan sesuaikan diri dengan orang lain. Dapat dikatakan bahawa pelajar lelaki lebih senang untuk bergaul dengan mana-mana pelajar sekalipun tidak kira agama, bangsa atau jantina. Dengan ini dapat dikatakan bahawa pelajar lelaki lebih mudah untuk sesuaikan diri mereka walau di mana mereka. Dapat dibincangkan bahawa berkemungkinan pelajar lelaki dilihat untuk lebih mudah berkawan dengan orang lain kerana mereka tidak bergaduh dengan hal-hal remeh dan pelajar lelaki adalah sejenis di mana mereka akan menolong rakan mereka yang berada dalam kesusahan. Sebagai contoh, jika secara tiba-tiba kereta rosak di tengah jalan pada waktu malam, jika meminta bantuan rakan lelaki, mereka dengan cepat akan datang untuk menolong. Pernyataan ini disokong oleh kajian lepas di mana pelajar lelaki dilihat lebih mesra dengan orang lain berbanding pelajar wanita (Ismail et. al., 2010).

Selain itu, dapatan kajian ini selari dengan kajian yang dilakukan oleh Safien dan Syuharul (2014) di mana pelajar lelaki dilihat kurang memberi tumpuan di dalam kelas berbanding pelajar perempuan. Pelajar perempuan dikatakan lebih outgoing dan mempunyai perhatian yang lebih tinggi ketika belajar. Berdasarkan hasil analisis, pelajar perempuan dilihat memiliki skor min yang lebih tinggi daripada lelaki kerana personaliti dan hal ini dapat disimpulkan bahawa mereka dilihat lebih rajin untuk belajar dan "confident" berbanding lelaki. Dapat dilihat, di dalam kelas pelajar perempuan kerap akan mendapat tempat terbaik dalam kelas dan lebih menyerlah dan konsisten dalam peperiksaan. Berbalik kepada pernyataan di atas, pelajar perempuan adalah lebih disiplin dalam apa yang dilakukan berbanding lelaki.

Seterusnya, untuk gaya pembelajaran visual, dapat dilihat bawa pelajar perempuan mendapat min yang tinggi dalam memberi fokus dan lebih mengingati sesuatu apabila menulis. Sebelum pelajar menulis nota, pelajar akan mendengar maklumat apa yang ingin ditulisnya, dan akan menulis mengikut apa 
yang difahami mereka. Apabila pelajar menulis nota, pelajar akan menulis apa yang penting sahaja dan ini adalah lebih efektif dari segi kefahaman pelajar itu sendiri. Ini disokong oleh kajian yang dilakukan oleh Yahaya (2005), di mana apabila cara untuk mengambil nota yang berkesan digunakan dengan betul, maka pelajar akan memperoleh keputusan yang cemerlang.

Min pelajar lelaki untuk gaya pembelajaran kinestetik adalah lebih tinggi berbanding perempuan kerana lelaki lebih kreatif dan artistik berbanding perempuan. Disokong oleh Ismail et. al. (2010) dimana lelaki lebih imaginatif dan tidak begitu konvensional berbanding perempuan yang lebih berhati-hati dan lebih konvensional. Walau bagaimanapun, saya tidak begitu setuju dengan pernyataan ini. Pada pandangan saya, perempuan adalah lebih kreatif dari lelaki kerana perempuan fikir sesuatu perkara dengan lebih. Lelaki adalah lebih mudah dalam melakukan sesuatu.

Dapatan kajian ini selari dengan dapatan kajian Nordin \& Mohammad (2018) di mana tiada perbezaan berkaitan motivasi akademik berdasarkan jantina Menurutnya, pelajar lelaki dan perempuan mempunyai motivasi yang sama. Seterusnya, dalam mengekal dan meningkatkan motivasi akademik dalam kalangan pelajar, banyak program dan aktiviti boleh dilaksanakan. Program dan aktiviti yang dilaksanakan akan menjadi mudah kerana aspek motivasi pelajar lelaki dan perempuan tidak berbeza secara signifikan.

Namun begitu, dapatan kajian ini bertentangan dengan kajian oleh Mahamod (2016). Kemungkinan besar perbezaan dapatan kajian adalah kerana perbezaan demografi responden dari segi jantina, kawasan tinggal, tahap pendidikan dan pekerjaan ibu bapa. Kajian yang dilakukan oleh Mahamod (2016) memberi fokus terhadap pelajar sekolah rendah tahun 6 di Iban dari 15 buah sekolah tetapi kajian ini memfokuskan hanya terhadap pelajar di satu universiti, secara perinci adalah Universiti Putra Malaysia. Berkemungkinan, pelajar tahun 6 memiliki motivasi akademik yang rendah akibat tertekan berhadapan dengan peperiksaan yang besar iaitu Ujian Pencapaian Sekolah Rendah (UPSR). Manakala, responden untuk kajian ini adalah pelajar tahun pertama Universiti Putra Malaysia. Sudah semestinya pelajar baru memiliki azam dan semangat yang berkobar-kobar dalam memulakan alam yang baru.

Selain itu, hasil dapatan menunjukkan responden perempuan mempunyai tahap motivasi intrinsik dan ekstrinsik yang lebih tinggi dari pelajar lelaki. Manakala untuk motivasi amotivasi, responden lelaki mempunyai tahap motivasi yang lebih tinggi berbanding perempuan. Dalam sebuah kajian yang dilakukan oleh Ahmad dan Manaf (2017) mendapati bahawa terdapat perbezaan yang signifikan antara motivasi ekstrinsik dengan jantina tetapi tiada perbezaan signifikan antara motivasi intrinsik dengan jantina. Dapatan kajian ini membuktikan bahawa penerimaan pembelajaran antara pelajar lelaki dan perempuan adalah tidak sama. Pelajar perempuan lebih seronok dan mempunyai kepuasan diri sendiri apabila melaksanakan sebarang tugasan

\section{Kesimpulan}

Secara keseluruhan, kajian ini telah berjaya mencapai objektif yang dinyatakan. Data yang diperoleh melalui pengedaran borang soal selidik dan soal selidik dalam talian kepada responden banyak membantu memberi maklumat yang diperlukan bagi melengkapkan kajian ini. Kajian ini dijalankan terhadap 351 responden tahun pertama di Universiti Putra Malaysia yang dibahagikan kepada dua kumpulan lelaki (117) dan perempuan (234). Data dikumpulkan melalui borang soal selidik dan borang soal selidik atas talian.

Dapat dirumuskan bahawa pelajar tahun pertama Universiti Putra Malaysia memiliki tahap konsep kendiri dan motivasi akademik yang tinggi. Pelajar tahun pertama Universiti Putra Malaysia lebih dominan dengan gaya pembelajaran visual dan kinestetik. Terdapat perhubungan yang positif antara konsep kendiri pelajar dengan motivasi akademik dan terdapat juga perhubungan yang signifikan antara gaya pembelajaran visual dan kinestetik dengan motivasi akademik pelajar. Oleh itu, gaya pembelajaran dan konsep kendiri dilihat mempengaruhi motivasi akademik para pelajar. 
Kajian ini juga merujuk dan membandingkan dengan kajian-kajian lampau yang mempunyai persamaan dan perbezaan terhadap dapatan kajian. Untuk kajian akan datang, dicadangkan untuk menggunakan pendekatan kaedah kualitatif untuk mendapat kesahan yang lebih tinggi. Cadangan hasil kajian agar dapat membuat bengkel kenali gaya pembelajaran yang diwajibkan untuk pelajar tahun pertama, program motivasi untuk memberi sokongan serta perhubungan dengan ibu bapa di mana memaklumkan prestasi anak mereka.

\section{Penghargaan}

Penghargaan kepada Mahasiswa/I Tahun Pertama, Sesi 2019/2020 Universiti Putra Malaysia (UPM) atas kesudian untuk bekerjasama untuk menghasilkan Disertasi Bacelor FEM4959-A \& B sebagai memenuhi syarat bergraduat dalam Bacelor Sains (Pembangunan Manusia dan Teknologi Maklumat), Fakulti Ekologi Manusia, Universiti Putra Malaysia.

\section{Rujukan}

A. (2018). "Saya gagal dan bodoh"- Luah pelajar sebelum gantung bunuh diri. Retrieved March 12, 2019, from http://www.astroawani.com/berita-dunia/saya-gagal-danbodoh-luah-pelajar-sebelumgantung-bunuh-diri-171089

Ahmad, M. Z., \& Manaf, M. F. A. (2017). Penggunaan Motivasi Intrinsik Dan Motivasi Ekstrinsik Untuk Belajar Bahasa Arab.

Aziz, N. A., Meerah, S. M., Halim, L., \& Osman, K. (2006). Hubungan Antara Motivasi, Gaya Pembelajaran Dengan Pencapaian Matematik Tambahan Pelajar Tingkatan 4. Ivasi, Gaya Pembel. Retrieved March 10, 2019, from http://journalarticle.ukm.my/187/1/1.pdf

Burns, R. B. (1981). The self concept. New York: Longman.

Cayubit, R., Castor, J., Divina, E., Francia, R., Nolasco, R., Villamiel, A., Villoria, A. I. S., Troy, M., \& Zarraga, M. (2014). A Q analysis on the impact of shadow education on the academic life of high school students. Psychological Studies, 59 (3), 252-259.

Correspondent, H. (2019). Board student kills himself for missing 5 questions of Physics paper. Retrieved March 13, 2019, from https://www.hindustantimes.com/education/board-student-killshimself-for-missing-5-questions-of-physics-paper/story-ZH5XRP9bIq7Dup7qMI0uyL.html

Daud, F., \& Mukhlisa, N. The Correlation between Learning Style and Learning Motivation: It's Influence on Students'learning of Biology.

Djamarah, S. B. (2011). Psikologi belajar. Jakarta: Rineka Cipta.

Dunn, R. \& Dunn, K. (1979). Learning Style/ Teaching Styles: Should they....can they be matched? Educational Leadership. January, 238 - 244.

Epstein, Seymour (1980), "The Self-Concept: A Review and the Proposal of an Integrated Theory of Personality." Personality: Basic Issues and Current Research, ed. Ervin Staub, Englewood Cliffs, NJ: Prentice-Hall.

Faizan, M. A. B., Nurul, A. C. D., \& Azlina. A. (2016). Hubungan antara Konsep Kendiri dan Motivasi dengan Pencapaian Pelajar Bagi Kursus Makroekonomi. Politeknik \& Kolej Komuniti Journal of Social Sciences and Humanities, 1(1).

Ghaedi, Z., \& Jam, B. (2014). Relationship between Learning Styles and Motivation for Higher Education in EFL Students. Theory \& Practice in Language Studies, 4(6).

Gokalp, M. (2013). The effect of students' learning styles to their academic success. Creative Education, 4(10), 627.

Hattie, J. (1992). Self concept. Hillsdale, NJ: Erlbaum.

Iredho,F. R. (2015). Hubungan antara motivasi akademik dengan prokrastinasi akademik pada mahasiswa. Humanitas: Jurnal Psikologi Indonesia, 12(1), 39-44.

Ismail, K. H., Anwar, K., Ahmad, S., \& Selamat, J. H. (2010). Profil Personaliti Bakal Calon Majlis Perwakilan Pelajar UKM: Suatu Perbandingan antara Lelaki dan Wanita. Jurnal Personalia Pelajar Bil, 13, 1-18.

Ismail, N. S., \& Rajuddin, M. R. (2012). Pengharapan pelajar bidang kejuruteraan di Kolej Komuniti terhadap aspek kerjaya (Doctoral dissertation, Universiti Teknologi Malaysia). 
Kar, N., Zarini, N., \& Saleh, S. (2012). Kesan Pendekatan Inkuiri Penemuan Terhadap Pencapaian Pelajar Dalam Mata Pelajaran Kimia. Journal of Educators \& Education/Jurnal Pendidik dan Pendidikan, 27.

Mahamod, Z. (2016). Sikap dan motivasi murid Iban dalam mempelajari Bahasa Melayu sebagai bahasa kedua. Jurnal Pendidikan Bahasa Melayu, 1(1), 13-25.

MARsH, H. W. (1990). The structure of academic selfconcept: The Marsh/Shavelson model. Journal of Educational Psychology 82(4): 623-636.

Marzuki Ngah. (2002). Hubungan antara konsep kendiri akademik, konsep kendiri bukan akademik dan motivasi pencapaian dengan pencapaian sains. Projek penyelidikan Ijazah Sarjana Pendidikan, Fakulti Pendidikan, Universiti Kebangsaan Malaysia.

Maulida, S. R., \& Dhania, D. R. (2012). Hubungan antara Kepercayaan Diri dan Dukungan Orang Tua dengan motivasi berwirausaha pada siswa SMK. Jurnal Psikologi, 11(2), 9.

Mohamadi Y, (2006). Understanding motivation and emotion. Reev JM. 4th ed. Tehran:Virayesh. Mohamadi Y, (Translator). [Understanding motivation and emotion]. Reev JM (Author). $4^{\text {th }}$ ed. Tehran:Virayesh, 2006,.[Persian].

Mohd, F. J., \& Shahizan, H. (2016). Kajian Penghargaan Kendiri Dan Kepuasan Hidup Pelajar (A Study Of Students'self Esteem And Life Satisfaction). Jurnal Psikologi Malaysia, 30(2).

Musa, K. E., \& Roach, M. E. (1973). Adolescent appearance and selfconcept. Adolescence, 8(31), 385.

Mustaffa, R. (2007). Mengadaptasikan gaya pembelajaran pelajar ESL: Satu kajian kes pelajar tahun satu di UKM. GEMA Online ${ }^{\circledR}$ Journal of Language Studies, 7(1).

Nasir, Z. M., \& Hamzah, Z. Z. (2013). Sikap Dan Motivasi Pelajar Terhadap Pembelajaran Bahasa Melayu [Abstract]. Retrieved March 2, 2019, from file:///C:/Users/acer/Downloads/Sikap_Dan_Motivasi_Pelajar_Terhadap_Pembelajara n_B.pdf.

National Association of School Psychologists. (2014). Academic Motivation: Strategies for Parents. Retrieved December 14, $2014 \quad$ from http://www.fcps.edu/LongfellowMS/pages/PTA/Academic\%20Motivation\%20-\%20 Strategies\%20for\%20Parents.pdf

Norlia Abd. Aziz, T. Subahan M. Meerah, Lilia Halim \& Kamisah Osman (2006). Hubungan Antara Motivasi, Gaya Pembelajaran Dengan Pencapaian Matematik Tambahan Pelajar Tingkatan 4. Jurnal Pendidikan, 31, 123 - 141.

Nordin, M. A., \& Mohammad, S. H. (2018, February). Hubungan Antara Motivasi Kendiri Dengan Pencapaian Matematik Pelajar Tingkatan 5 Di Daerah Rompin. In iCompEx18 Pembentangan Kertas Penyelidikan Akademik.

O’Brien, L. (1990). The learning channel preference checklist. In J. M. Reid (Ed.), 1995, Learning styles in the ESL/EFL classroom (pp. 196-201). Boston, MA: Heinle \& Heinle.

O'Connor, T. (1997). Using learning styles to adapt technology for higher education. Retrieved May 20, 2013 from http://www. Ind State. Edu/ctl/styles/learning. Html Pelajar tikam diri dipercayai stres akibat pelajaran. (2018). Retrieved March 10, 2019, from https://www.utusanborneo.com.my/2018/01/31/pelajar-tikam-diri-dipercayai-stresakibatpelajaran

Potter \& Perry. (2005). Fundamental Keperawatan. Jakarta : EGC.

Ramos, R. M., Cayubit, R. F. O., Ang, M. C. R., Arconado, J. A. M., Castillo, B. M. C., Paz, R. A. \& Villasenor, C. N. C. (2012). Academic Motivation and Learning Styles of College Freshmen Exposed to Shadow Education. Philippine Journal of Psychology, 45(1), 95-110.

Rashid, R. (2007). Hubungan antara gaya pembelajaran dengan motivasi dalam kalangan pelajar di sebuah sekolah menengah luar bandar, Sabah (Doctoral dissertation, Universiti Teknologi Malaysia).

Razak, A. (2018). Pelajar Straight A SPM Bunuh Diri Terjun Bangunan Kerana Depresi. Retrieved March 10, 2019, from https://lobakmerah.com/pelajar-straight-a-spmbunuh-diri-terjun-bangunankerana-depresi/

Rijal, S., \& Bachtiar, S. (2015). Hubungan antara Sikap, Kemandirian Belajar, dan Gaya Belajar dengan Hasil Belajar Kognitif Siswa. Jurnal Bioedukatika, 3(2), 15-20.

Safien, A. B., \& Syuharul, N. (2014). Kajian terhadap perbezaan pencapaian SPM pelajar lelaki dengan pelajar perempuan dan faktor yang mempengaruhinya.

Saputra, W. N. E., \& Prasetiawan, H. (2018). Meningkatkan Percaya Diri Siswa melalui Teknik Cognitive Defusion. Jurnal Kajian Bimbingan dan Konseling, 3(1), 14-21. 
Stuart, W \& Sundeen, J. (1998). Buku Saku Keperawatan Jiwa, edisi 3. Jakarta : EGC.

Sulaiman, Z., \& Jasmi, K. A. (2013, June). Gaya Pembelajaran dan Hubungannya dengan Motivasi Pelajar: Satu Kajian Tinjauan di Pusat Pendidikan Andalus Peringkat Menengah di Singapura. Seminar Pasca Siswazah Pertama. Fakulti Tamadun Islam, Main Hall, Faculty of Islamic Cilization, Universiti Teknologi Malaysia

Talib, N. H. F. B., Mohd Shafie, B. H. B., Ahmad, J. B., \& Tamuri, A. H. (2014). Hubungan Konsep Kendiri dan Motivasi Pelajar Dengan Pencapaian Kursus Di Sebuah Politeknik. International Journal of Islamic Studies and Arabic Language Education, 1(1).

Tarwoto \& Wartonah. (2003). Kebutuhan Dasar Manusia dan Proses keperawatan, edisi 3. Jakarta : Salemba Medika.

Tawi, F. B. M. T. (2019). Motivasi pencetus kejayaan akademik pelajar.

Vallerand, R.J., Pelletier, L.G., Blais, M.R., Brière, N.M., Senècal, C., \& Vallières, E.F. (1992). The Academic Motivation Scale: A measure of intrinsic, extrinsic, and amotivation I education. Educational and Psychological Measurement, 52(4), 1003- 1017.

Wehrwein, E. A., Lujan, H. L, \& DiCarlo, S. E. (2007). Gender differences in learning style preferences among undergraduate physiology students. Advances in physiology education, 31(2), $153-157$.

Wulandari, R. (2011). Hubungan Gaya Belajar dengan Prestasi Belajar Mahasiswa Semester IV Program Study D IV Kebidanan Universitas Sebelas Maret. Jurnal Kesehatan Kusuma Husada.

Yahaya, A. (2005). Hubungan Antara Konsep Kendiri, Motivasi Dan Gaya Keibubapaan Dengan Pencapaian Pelajar (Doctoral dissertation, Universiti Teknologi Malaysia).

Yahaya, A. (2005). Aplikasi kognitif dalam pendidikan. PTS Professional.

Zahara. 2000. Hubungan antara konsep kendiri dan motivasi pencapaian dengan pencapaian dalam mata pelajaran Sejarah. Tesis Sarjana, Fakulti Pendidikan, Universiti Kebangsaan Malaysia. 